\title{
The Determinants of Earnings: A Behavioral Approach
}

\author{
Samuel Bowles \\ Herbert Gintis \\ Melissa Osborne*
}

January 26, 2001

\section{Introduction}

Enhancing individuals' capacity to succeed in the labor market is a major objective of both families and policy makers, one which in recent years has assumed special urgency with respect to those with low earnings. According to the canonical model, earnings are determined by human capital, which consists of capacities to contribute to production, generically called skills. Individuals possess a vector of these capabilities, $c$ and sell these on the labor market at hourly prices $\mathrm{p}$, with hourly earnings $w=p c$. But we know surprisingly little about what the what skills make up the vector of individual capabilities contributing to higher earnings, and as we will see, some common beliefs about the earnings-generation process receive little support from available data.

However, recent developments in labor econometrics and the microeconomics of labor markets provide the basis for a reconsideration of the determinants of individual earnings. We here survey what is known about the determinants of individual earnings and, drawing on a number of recent contributions, propose a behavioral

\footnotetext{
*Samuel Bowles: Santa Fe Institute and University of Massachusetts; Herbert Gintis: University of Massachusetts; Melissa Osborne: Towson University. We would especially like to thank James Heckman, Susan Mayer and Yona Rubinstein for their comments. We would also like to thank Roland Bénabou, Anne Case, Angus Deaton, William Dickens, John Dinardo, Greg Duncan, Steven Durlauf, Paula England, Henry Farber, Daniel Hamermesh, Karla Hoff, Min-Hsiung Huang, Melvin Kohn, Michael Kremer, Alan Krueger, Charles Manski, Casey Mulligan, Richard Murnane, William Nordhaus, Mark Rosenzweig, Cecilia Rouse, and Eric Olin Wright for providing unpublished estimates, comments and other assistance, as well as participants at seminars at Yale University, the University of Chicago, MIT, and the University of Wisconsin, and the Journal of Economic Literature's anonymous reviewers, for comments on earlier drafts, Bridget Longridge for research assistance, and the MacArthur Foundation for financial support.
} 
model that is capable of addressing the following puzzles in a parsimonious and non-ad hoc manner.

First, apparently similar individuals receive quite different earnings: a person's age, years of schooling, years of labor market experience, parents' level of schooling, occupation and income tell us surprisingly little about the individual's earnings. In standard earnings equations for individuals of the same race and sex in the United States, between two thirds and four fifths of the variance of the natural logarithm of hourly wages or of annual earnings is unexplained by the above variables. Some of the unexplained variance is contributed by the transitory component of earnings and response error (Solon 1992, Zimmerman 1992, Bowles 1972). But this leaves well over half of the variance of the natural logarithm of permanent earnings unexplained by the standard demographic variables. ${ }^{1}$ The puzzle is to understand the sources of these unexplained earnings differences.

Second, success in the labor market is transmitted from parents to children, and the advantages of the children of successful parents go considerably beyond the benefits of superior education, the inheritance of wealth, or the genetic inheritance of cognitive ability. ${ }^{2}$ Variables measuring the occupation, education, or income of one's parents typically remain significant predictors in earnings equations that include measures of years of schooling, schooling quality, and either a childhood or adult measure of cognitive functioning. Casey Mulligan (1999) controls for a large number of measures of school quality as well as the Armed Forces Qualification Test (a cognitive test developed to predict vocational success) as well more standard educational and demographic variables and nonetheless finds that an estimate of parental income is an important (and statistically significant) predictor of the natural logarithm of the hourly wage rate in 1990 and 1991 in the National Longitudinal Study of Youth, a bit more than two fifths of the gross statistical association between parental and offspring economic success apparently operating independently of the influences of these conditioning variables. ${ }^{3}$ Bowles and Valerie Nelson (1974) found that between a third and three fifths of the covariation of parental economic status and respondent's income was not accounted for by the statistical association

\footnotetext{
${ }^{1}$ Race and sex are strong predictors of earnings. We here confine ourselves to explaining earnings differences among people of the same race and sex.

${ }^{2}$ The current literature is surveyed in Bowles and Gintis (2001).

${ }^{3}$ Specifically, the effect of an estimate of the logarithm of parental income on offspring's $\ln (w)$ in a regression conditioned on schooling, employment, or cognitive performance is between two fifths and a half of the estimated effect of parental income unconditioned on these variables. Mulligan's work repeats, as have a number of other studies, the finding in Atkinson, Maynard and Trinder (1983) for a sample with direct measures of incomes of fathers and sons in the United Kingdom in which two thirds or more of the substantial intergenerational transmission of income status is independent (in the sense just defined) of the covariation of parental income with a range of measures of son's schooling.
} 
of parental status with childhood IQ or years of schooling. ${ }^{4}$ Bowles and Nelson estimated that even if the heritability of measured intelligence were as high as 0.8 , an estimate now thought to be considerably too high (Otto, Christiansen and Feldman 1995, Devlin, Daniels and Roeder 1997), the genetic inheritance of this trait would account for only about a tenth of the observed association between parental and offspring economic status. ${ }^{5}$. The puzzle is to understand what it is that successful parents pass on to their children that gives them labor market advantages beyond the superior schooling and cognitive scores measured in the available studies.

Third, seemingly irrelevant personal characteristics, including beauty, height, obesity, and even whether one keeps a clean house, are often robust predictors of earnings. Daniel Hamermesh and Jeff Biddle (1994) found that for United States and Canadian employees the expected hourly wage difference between men judged to be "below average" and those with "above average" looks was 14 per cent of the expected wage, with the "looks premium" for women being around 9 per cent. Both premia were estimated in a standard earnings equation with additional regressors including health status, marital status, occupation and industry. ${ }^{6}$ Greg Duncan and Rachel Dunifon (1997) found that the Panel Study of Income Dynamics interviewer's assessment of whether the respondent's home was clean is a good predictor of earnings years later in a rather complete earnings function, taking account of a wide range of motivational and attitudinal variables as well as the more conventional educational, cognitive, and demographic influences. A standard deviation difference in the measure of home cleanliness is estimated to affect a change in earnings over half as large as a standard deviation difference in years of schooling. The puzzle is to explain why these apparently irrelevant traits earn a competitive reward in labor markets.

Finally, some assessments of the efficacy of the educational system and the pro-

\footnotetext{
${ }^{4}$ The data for the Bowles-Nelson study are a 1962 sample of 'non-Negro' males from non-farm backgrounds. For the earlier period, see also Otis Dudley Duncan (1968).

${ }^{5}$ Of course some successful parents pass on wealth to their children but we doubt that this adequately accounts for the importance of parental economic success in predicting the success of offspring, if for no other reason that a large majority of children (about three quarters) receive no inheritance (Mulligan, (1999):227)

${ }^{6}$ James Sargent and David Blanchflower (1998), using longitudinal data from the British National Child Development Study found that having been obese at age 16 contributed to a woman's low earnings at age 23 irrespective of whether she was obese or lean at the later age (with obesity at the later age having no independent effect for those who were obese at 16), a finding consistent with the view that it is not obesity per se but durable psychological or behavioral concomitants of obesity that account for at least some of these results. See also Sobal and Strunkard (1989), Eng Seng Loh (1993), Charles Register and Donald Williams (1990), Sobal (1991), Strunkard and Sorensen (1993), Susan Averett and Sanders Korenman (1996) and Jere Behrman, et al., (1994). Obese women and thin men appear to be penalized, and tall men favored, though the results for men are not entirely consistent across studies.
} 
ductivity of school resources have centered on cognitive achievement scores, while others have emphasized the effect of schooling on earnings independently of cognitive scores. ${ }^{7}$ Reviewing research in this area, Gary Burtless (1996):4 comments:

One set of findings implies that added school resources produce little if any measurable improvement in students' academic performance while youngsters are in school. The other suggests that extra school resources can improve the job market success of school graduates. Researchers and policy makers are left with a puzzle.

The puzzle is to explain why the apparent impact of school resources on earnings might be so different from their apparent effects on subsequent earnings.

The substantial size of the residual variance in earnings equations, the importance of parental social status and other traits seemingly bearing no direct relationship to individual capabilities used in the production process, and the conflicting evidence on the effectiveness of school resources are puzzling from the standpoint of the canonical human capital model, which attributes earnings differences to differences in productive skills. By a productive skill we mean an individual capacity that contributes to production by providing a service that appears as an argument in the production function. ${ }^{8}$ For simplicity we will call these 'skills' without implying that other capacities that do not appear in production functions-athletic, artistic, and the like-do not involve the use of skills. Productive skills are influenced by genetic inheritance, and are acquired through learning from parents, neighbors and friends, schooling, work experience, and by other means. Because earnings differences are attributable to skill differences in the conventional view, 'residual inequality' - the unexplained variance of earnings within education-experience cells-is held to be the result of 'unobserved skill.' The skill most commonly thought to explain residual variance is cognitive functioning. While other individual attributes, strength, for example, are certainly skills at least in some jobs, few noncognitive skill-related traits have been measured. ${ }^{10}$

\footnotetext{
${ }^{7}$ The evidence of effects of school resources on later earnings that is presented in Card and Krueger (1996), Betts (1995), and Heckman, Layne-Farrar and Todd (1996) suggest that these results may be fragile. The papers in Burtless (1996) review this debate.

${ }^{8}$ What counts as a skill thus depends not only on the production function but also on the division of labor and other aspects of the organizational structure of the firm. Where employees have a wide latitude for making complicated decisions their advanced computational capacities might be a skill, while this would not be the case if they make only simple decisions.

${ }^{9}$ Thus Katz and Murphy (1992) write: "We use the dispersion of relative wages within our sexeducation-experience cells as measures of the spread in relative wages across different skill levels within cells." (p. 43) And Juhn, Murphy and Pierce (1993) write: "we view this increase in withingroup wage inequality as a trend toward higher skill prices." (p. 423)

${ }^{10}$ Nutritional and health status have been shown to directly affect labor productivity in a number of poor countries. See Foster and Rosenzweig (1993) and the studies cited therein.
} 
The availability of data on cognitive performance scores on dozens of test instruments appears to have crowded out other reasonable hypotheses concerning less copiously measured individual attributes. Three examples of the importance of the latter are the following. The first is from a recent survey of 3,000 employers conducted by the United States Census Bureau in collaboration with the Department of Education (Bureau of the Census 1998) which asked "When you consider hiring a new nonsupervisory or production worker, how important are the following in your decision to hire?" Employers ranked "industry based skill credentials" at 3.2 on a scale of 1 (unimportant) to 5 (very important), with "years of schooling" at 2.9, "score on tests given by employer" and "academic performance" both at 2.5. By far the most important was "attitude" ranked 4.6, followed by "communication skills" (4.2).

The second example is from the far more detailed Employers' Manpower and Skills Practices Survey of 1693 British employers reported in Green, Machin and Wilkenson (1998). Of the somewhat more than a third of the establishments reporting a "skill shortage", personnel managers identified the recruitment problem as "lack of technical skills" in 43 percent of the cases, but "poor attitude, motivation, or personality" in a remarkable 62 percent of the cases. Poor attitude was by far the most important reason for the recruitment difficulty given. The importance of motivation relative to technical skill was even greater among the full sample.

The third example is from a series of studies (Heckman, Hsee and Rubinstein 1999, Cameron and Heckman 1993, Heckman forthcoming) on the labor market impact of the GED, a diploma gained by a test of cognitive skills taken by a large fraction of dropouts from United States high schools. GED holders exhibit substantially better cognitive performance than other high school dropouts. ${ }^{11}$ But behavioral and personality problems, evidenced by delinquent and illegal behaviors, account for the fact that the GED's wages are barely higher than other less cognitively skilled dropouts and are perhaps ten percent below the levels which would be predicted on the basis of their cognitive skills and other conventional earnings determinants. Heckman and his coauthors reason that the GED is a "mixed signal" indicating to employers that the individual had the cognitive skill to complete high school but lacked the motivational or behavioral requisites. Their data are also consistent with the view that the economic returns ot schooling depend on "seat time;" i.e., being there may be more important than learning the ew curriculum.

All three examples illustrate a possible bias: we tend to refer to "skill shortages" when we mean any difficulty in recruiting or retaining suitable employees. Among economists, at least, other more conceptual biases are at work, the main one being

\footnotetext{
${ }^{11}$ Murnane, Willett and Tyler (1998) confirm these results using the High School and Beyond data base.
} 
the presumption that anything rewarded in a competitive labor market must be a skill. Our essay is addressed to this second bias which, if we are correct, acquires its plausibility by default, there being no widely accepted model of why individual traits that are not skills might be rewarded in a competitive labor market equilibrium.

Such a model, however, is readily provided, even within a fully competitive framework. If disequilibrium rents arising from technological or other shocks are persistent and if labor services are not subject to costlessly enforceable contracts, individual behavioral traits unrelated to productive capacities may bear a positive price. We use the term 'behavioral trait' to refer to aspects of the individual that are not productive skills as defined above. For example, aspects of an individual's personality such as fatalism or impatience may reduce the likelihood of capturing disequilibrium rents and dampen the employee's response to common employer strategies aimed at eliciting high levels of labor effort. The result in both cases is that individual with these personality traits will earn less. Moreover, as we will see, the behavioral traits that contribute to high earnings in some jobs may have negative effects in other situations. For example, individuals who prefer not to subordinate themselves to others will be highly successful in some jobs, but abject failures in others. Representing the economy as a dynamical system often in disequilibrium, and in which the quality and quantity of labor effort is not subject to enforceable contracts, is both a step towards a more realistic foundation for labor economics and one that provides important insights about the nature of skill and the independent contribution that behavioral traits may make to earnings. Understanding why individual characteristics that are not skills may be rewarded in a competitive labor market may enhance the explanatory power and policy relevance of the human capital model by shedding some light on how schooling and other human investments raise individual earnings.

\section{Walrasian, Schumpeterian, and Coasean Determinants of Earn- ings}

Earnings differences will be attributable entirely to skill differences in what we will term a 'Walrasian model,' that is, one in which the vector of services that an employee provides to the production process per hour of work, $c$, is an exogenously determined attribute of the worker, and markets equilibrate sufficiently rapidly that we may abstract from disequilibria. This is the conventional labor market model in which the law of the single price ensures that productively identical individualsthose with identical $c$-vectors-will receive the same wage in all employments. Léon Walras made it clear that the behavioral characteristics of the parties to an exchange may be ignored: "Assuming equilibrium, we may even go so far as to 
abstract from entrepreneurs and simply consider the productive services as being, in a certain sense, exchanged directly for one another..." (1954/1873:225). The fiction that services directly exchange for one another without human intervention is a handy simplification for the analysis of equilibria of an economy with complete contracting.

However if, contra Walras, equilibrium is not assumed, the law of the single price is no longer in force and we have a what we term a Schumpeterian model of earnings determination in which at any given moment factor payments typically include what may be termed "disequilibrium rents." Joseph Schumpeter attributed these rents to technical change, product innovation, changes in business organization, and other shocks. People differ in their ability to identify and capture these disequilibrium rents, and the personal dispositions and capacities contributing to success in this may correspond only weakly to productive skills. In contrasting "two types of individuals: mere managers and entrepreneurs" Schumpeter (1911/1934:81-3) observed: "the type of conduct in question not only differs from the other in its object 'innovation' being peculiar to it but also in that it presupposes aptitudes differing in kind and not only in degree from mere rational economic behavior. ...Many a one can steer a safe course, where no one has yet been, others follow where first went another; still others only in the crowd, but in this among the first." T. W. Schultz, in these pages (1975):827 termed the capacities of Schumpeter's generic entrepreneurial types, "the ability to deal with disequilibria" and attributed a significant portion of the economic return to schooling to the enhancement of these abilities through education.

(a)

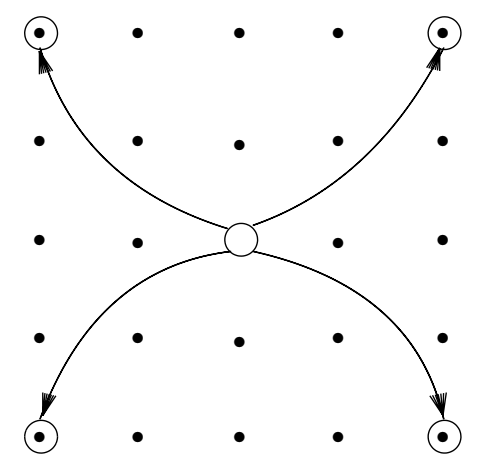

(b)

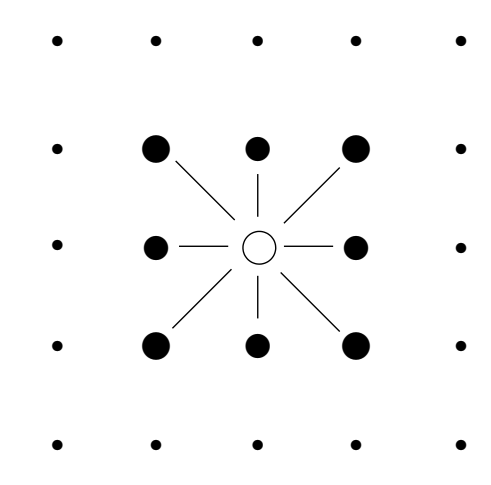

Figure 1: The Search Process: One round of inspection by a Schumpeterian entrepreneur consists of a relocation to a randomly chosen node two steps away (a), followed by an inspection of the new node and its immediate neighbors (b) for a high yield node. 
To see why Schumpterian traits may enhance incomes, we simulate an economy in which profitable economic opportunities are spatially dispersed, agents search for opportunities in a region around their current locations, more 'enterprising' agents are capable of more sustained searches, and technical change takes the form of profitable opportunities randomly relocating at a given rate per period. We model this economy as a $75 \times 75$ lattice arranged as a torus (i.e., the right and left edges of the lattice are identified, as are the top and bottom edges, and nodes are points where a row and a column intersect). At the beginning of the simulation agents are assigned randomly to about ten percent of the nodes, and about one percent of the nodes are randomly designated as have high-yield payoffs, the rest having low yield.

We randomly assigned each agent from one to ten levels of 'Schumpeterian entrepreneurship.' A search move at a low-yield node involves first relocating randomly two steps on a diagonal from the present position (pane (a) of Figure 1); second, inspecting the new node and its immediate eight neighbors for high-yield (page (b) of Figure 1); and finally relocating to a high-yield node if found. An agent with level $k$ entrepreneurship executes search moves until a high-yield location is discovered, but for a maximum of $k$ rounds.

Technological change of rate $r$ in the simulation takes the form of a fraction $r$ of high-yield nodes randomly relocating in each period. Figure 2 shows the result of a typical set of simulations for rates of technical change ranging from zero to eleven per cent, where the level of Schumpeterian entrepreneurship varies from one to ten.

This idea was first explicitly formalized by Richard Nelson and Edmund Phelps (1966). They model a process of technical diffusion in which the time lag between the creation of a new technique and its adoption is a decreasing function of the educational attainments of those in a position to innovate. An important implication of their model is that the rate of return to education is greater the more rapid the rate of technical change. They conclude (p.75): "the usual straightforward insertion of some index of educational attainment in the production function may constitute a gross misspecification of the relation between education and the dynamics of production." Finis Welch (1970:42) developed this idea further:

the productive value of education has its roots in two distinct phenomena. Increased education may simply permit a worker to accomplish more with the resources at hand. ...[or it may] enhance a workers ability to acquire and decode information about costs and productive characteristics of other inputs. As such a change in education results in a change in other inputs including perhaps the use of some 'new' factors that otherwise would not be used.

Welch termed the first the 'worker effect' and the second the 'allocative effect' of 


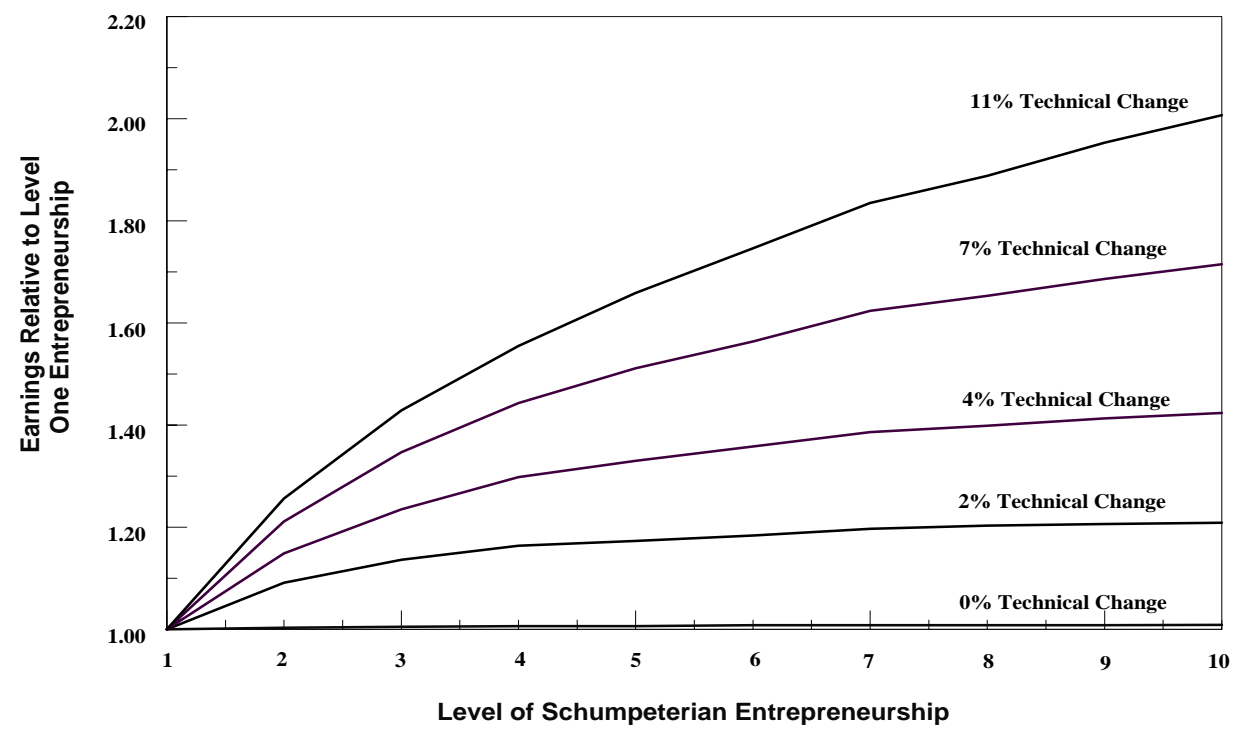

Figure 2: Schumpeterian Entrepreneurship, Earnings, and the Rate of Technical Change. Those who search more widely earn more, and this "Schumpeter effect" on earnings is greater the more rapid is technical change.

schooling.

While Welch, Nelson and Phelps focused on education effects, individuals with similar educations may differ greatly in degree of risk aversion, degree of self-directedness, the belief that one's own actions are effective in determining outcomes - 'internality' as opposed to 'fatalism' — and other traits likely to enhance one's ability to deal with disequilibria. Thus a wide range of individual non-skill related traits may be important determinants of earnings. We shortly present evidence that the economic returns to these capacities may be considerable.

If the other assumption of the Walrasian model-exogenous determination of the delivery of the employee's productive services-is dropped, a new set of nonskill traits may become earnings determinants. Individual traits may be relevant to attenuating the incentive problems that arise when labor effort is endogenous. These incentive enhancing preferences, as we shall term them, may bear a competitive return even if they do not contribute directly to production. We call this the Coasean model of earnings determination because the theory of the firm due to Ronald Coase clearly recognized the importance of the employer's authority and incentive-making capacity in structuring work and pay. Coase wrote (1937): "...note the character of the contract into which a factor enters that is employed 
within a firm....the factor...for a certain remuneration... agrees to obey the directions of the entrepreneur." While the Coasean model is a forerunner of modern principal-agent models of the employment relationship, the implications of this model for the income determination process have been most fully explored not by economists but by sociologists.

Sociological accounts frequently stress the non-skill related determinants of earnings and of the contribution of schooling to the economy, often under the heading of 'socialization for work. ${ }^{\text {'12 }}$ Until recently, economists have ignored this literature, arguing that an employer would be no more willing to pay a premium for the services of a 'well socialized' worker than a shopper would be to pay a higher price for the fruit of a 'well socialized' grocer. However this reason for ignoring incentive enhancing preferences is inconsistent with the microeconomics of the labor market based on asymmetric information, which holds that the employment relationship is generally contractually incomplete and hence employee effort (and hence the delivery of productive services to the employer) is endogenous. ${ }^{13}$

A costlessly enforceable promise of a wage is exchanged not for costlessly enforceable labor services but rather for the employees' agreement to accept the employer's authority during the hours of work. ${ }^{14}$ This authority is then used to secure the flow of labor services that, when combined with other productive inputs, produces output. We refer to this use of the employer's authority as the endogenous enforcement of the labor contract. In such a situation employers may choose to pay for incentive-enhancing preferences. ${ }^{15}$ Examples of such profitable individual traits are a low time discount rate, a predisposition to truth telling, identification with the objectives of the firm's owners and managers as opposed to the objectives of co-workers or customers, a high marginal utility of income, and a low disutility of effort.

Just as the employer's valuation of productive skills of employees will depend on the product mix and production functions in use, as well as organizational and other influences on the division of labor within the firm, the value of incentiveenhancing preferences will vary with the nature of the endogenous enforcement problem. Where monitoring is impossible, for example, the importance of truth telling might be heightened. Where one employee is expected to monitor other

\footnotetext{
${ }^{12}$ See Parsons (1959) and Dreeben (1967).

${ }^{13}$ Indeed, the theory of social exchange (Blau 1964) that underlies the sociological account of schooling as influencing individual preference structures, is recognizable to an economist as a theory of incomplete contracts.

${ }^{14}$ Gary Becker (1964) observed that in this case "any enforceable contract could at best specify the hours required on a job not the quality of the performance," (p. 6) but the subsequent development of human capital theory did not take account of the important implications of this insight.

${ }^{15} \mathrm{We}$ formalize this model in Bowles, Gintis and Osborne (2001).
} 
employees, different behavioral traits, physical characteristics or modes of selfpresentation, or costly to acquire credentials contributing to the legitimacy of the exercise of authority, might be highly valued by employers. The following model, developed in Bowles et al. (2001), illustrates this argument.

Suppose the amount of labor services an employee supplies to a firm is the product of three terms: the capacities of the worker, $c$, which we take as given, the number of hours $h$ worked, and the employee's effort level $e$, where $0 \leq e \leq 1$. We assume the employer can contract for hours $h$, but effort $e$ is not verifiable and hence cannot be determined by contractual agreement. However the employer has an imperfect measure of $e$ that indicates with probability $\tau(e)$ that the employee has 'shirked,' where $\tau^{\prime}<0$. Employees whose shirking is detected are dismissed and take their next best alternative (e.g. unemployment insurance and job search). The difference between the present value of utility for a person holding a job and for one just dismissed from a job is termed the employment rent or the cost of job loss. The employer's threat to deprive employees of the job rent motivates employees to provide higher levels of effort than they would in the absence of the threat.

We will model the employer-employee relationship as an infinitely repeated game in which the employer hires a team of $h$ employees, each of whom works for one hour, and is paid a wage $w$ at the end of the period. An employee discovered shirking is dismissed and replaced by a new employee (identical to the one replaced), also at the end of the period. The employer as first mover chooses $h$ and $w$ to maximize profits, in the knowledge that a higher wage may induce the employee to supply more effort, since the cost of job loss increases with the wage. The employee then chooses effort $e$ to maximize the present value of expected utility. We call this a contingent renewal model of the employment relationship. ${ }^{16}$

Our model of incentive enhancing preferences depends on the employee's best response function $e=e(w)$, which shows the level of effort $e$ chosen by a employee faced with a wage rate $w$. The employee chooses the level of effort that equates the marginal disutility of effort to the cost of job loss times the marginal effect of increased effort on the probability of job loss.

We say an aspect of the employee's preferences is incentive-enhancing if an increase in $a$ shifts up the best response function $e(w)$. Thus an increase in incentive enhancing preferences will lead an employee to work harder, holding all else constant.

Here are three examples of incentive enhancing preferences. ${ }^{17}$ First, it is easy to see that a reduction in the individual's rate of time preference-that is, a greater

\footnotetext{
${ }^{16}$ Contingent renewal models of this type are analyzed in Gintis (1976), Shapiro and Stiglitz (1984), Bowles (1985), and Gintis and Ishikawa (1987).

${ }^{17}$ The argument in the remainder of this section a summary of the theorems presented in Bowles and Gintis (1999).
} 
orientation toward the future-is an incentive enhancing preference as it raises the importance, in the individual's evaluations, of the prospect of retaining the job in the future and thus in avoiding any behavior that might result in termination.

Second, individuals differ greatly in the strength of their sense of personal efficacy, a personality trait frequently measured (inversely) by the so-called Rotter scale. Highly fatalistic, low efficacy persons believe that their actions have little impact on the outcomes they experience. We thus rewrite the termination probability as $\tau(e, f)$ where $f$ is the Rotter measure of fatalism and $\tau_{e f}>0$, so that by comparison with those with a greater sense of personal efficacy, more fatalistic people believe that their work effort has less effect on the probability of their job termination. Because greater fatalism lowers the absolute value of $\partial \tau / \partial e$, it lowers the marginal subjective benefit to exerting effort and so reduces the employee's desired effort level. So fatalism is an incentive-depressing trait (efficacy is incentiveenhancing).

Third, suppose an increase in $a$ increases utility derived from the job relative to the state of being without a job and does not increase the marginal disutility of effort. Then $a$ enhances incentives by increasing the desirability of holding the job, thus increasing the employee's optimal choice of effort. Examples of such an increase in an incentive-enhancing trait are an increase in the marginal utility of income or an increase in the level of shame experienced at being without work or receiving public transfers, for instance in the form of unemployment insurance. ${ }^{18}$

Other traits may also be important, as can be seem by extending the above model to take account of individual behaviors that disrupt production. Suppose each individual undertakes two behaviors. In addition to the level of effort, $e$, described above, the employee also implements a level of helpful or disruptive behavior towards other employees, perhaps encouraging others or picking fights and complaining about working conditions, thus lowering morale. For simplicity, suppose there are two identical workers such that if one worker chooses disruptive level $\delta<1$ and the other chooses effort level $e$, then the second worker's effective effort $e^{*}$ is given by $e^{*}=e(1-\delta)$. As in the case of effort elicitation, the employer uses an incentive system designed to limit disruptive activities-and to encourage helpful activities, which satisfy $\delta<0$-by dismissing disruptive employees; i.e., by adopting a termination function for an employee given by $\tau=\tau(e, \delta)$ with $\partial \tau / \partial \delta>0$. Employees then choose a level of disruptive behavior that balances the marginal costs of foregoing a disruption (enduring an insult from a fellow worker, for example) and the marginal benefits of restraint (increased probability of retaining

\footnotetext{
${ }^{18}$ Even in the case of complete and costlessly enforceable contracting, which is of little empirical importance, behavioral traits that are not skills may predict hourly earnings. For instance, if payment is by straight piece rates, the level of effort chosen by the employee will determine the number of pieces produced, so highly motivated employees will have higher hourly earnings.
} 
the job). Since the employees are homogeneous, we can write the effect effort of each as $e^{*}(w)=e(w)(1-\delta(w))$, where $e(w)$ is the worker's best response effort level and $\delta(w)$ is the other worker's best response level of disruption. We can then define an incentive-enhancing trait as one that either increases $e$ or lowers $\delta$ for given levels of the other variables. As we will see, disruptive traits such as picking fights or being aggressive may bear negative labor market rewards.

We may summarize the importance of incentive-enhancing preferences by representing the production process as a two-equation system including not simply by a production function (1) but the employee's best response functions (2) and (3) as well:

$$
\begin{aligned}
& y=y(h \lambda(e(1-\delta), c), k) \\
& e=e(w) \\
& \delta=\delta(w) .
\end{aligned}
$$

where $c$ is a vector of productive capacities of the worker (skills), $e$ is the level of effort, $\lambda(e(1-\delta), c)$ represents hourly labor services devoted to the production process, $h$ the number of hours of labor hired, $k$ is a vector of all other inputs, and $a$ is a vector of characteristics of the employee including such traits as the rate of time preference, efficacy, the disutility of labor and the utility of income mentioned above.

We turn now to consider empirical evidence on skills and incentive-enhancing preferences as determinants of earnings. By far the most extensively studied individual traits concern cognitive functioning, the importance of which we will consider first before turning to evidence on other traits. Cognitive functioning may be a skill (as is the case with the use of computational skills on the job) or an income earning non-skill trait, as is the case where cognitive ability is critical to recognizing and capturing disequilibrium rents, or where, as in the above example of time preference, having a sufficiently vivid view of the future to make the distant benefits of job tenure salient to one's behavior.

\section{Cognitive Performance, Schooling and Earnings}

The independent importance of both schooling and cognitive functioning as earnings determinants is uncontroversial. Moreover, there is no longer much doubt but that those with more schooling have higher earnings substantially because they are educated, and not solely because schooling covaries with ability, parental social status and other traits rewarded in the labor market. ${ }^{19}$ While schooling appears also to perform a credentialing function, the magnitude of the resulting diploma 
effects, where these have been identified, represent a small proportion of private economic return to schooling. ${ }^{20}$ Finally, schooling enhances performance on cognitive tests: controlling for prior ability and a large number of other possible influences on cognitive performance, those who remain in school longer score higher on tests (Christopher Jencks and Meredith Phillips 1996, and Christopher Winship and Sanders Korenman 1997).

Because schooling increases earnings and also imparts cognitive skills, many have supposed that the acquisition of cognitive skills is the mechanism whereby schooling increases earnings. Why else would employers pay the education premium? Tacitly accepting this argument, economists tend to equate differences in levels of schooling with skill differences. Yet aside from the generic skills measured on such tests as the AFQT (to which we will return) it has proven remarkably difficult to give an adequate account of the skills that schools produce and to document their reward in labor markets.

The most straightforward approach is to ask what schools teach and to consider the economic returns to the resulting curricular outcomes. It is not difficult to identify individual characteristics that are acquired through instruction and that also appear to raise earnings. But these characteristics typically explain only a small fraction of the observed economic return to schooling. Thus the economic contribution of the curricular content of schooling has proven elusive. Altonji (1995), for example, found that additional years of science, math, and foreign language in high school contribute to subsequent earnings, but that the value of courses taken in a year of high school in terms of enhanced earnings is considerably less than the value of an additional year of high school. ${ }^{21}$ Moreover, those school programs most deliberately designed to contribute to occupational skill enhancement-vocational programs - appear to have limited success (Altonji 1995).

A more promising approach might be to define skills broadly as generic cognitive capacities, and to explore the contribution of schools to labor-market success via

\footnotetext{
${ }^{19}$ See Card (1998) for a survey of recent studies of the returns to schooling in the United States. Taking account of the endogenous determination of years of schooling appears, if anything, to raise the estimated returns to schooling in most cases. See also Ashenfelter and Krueger (1994). However Altonji (1995) finds a substantial reduction in the estimated return to schooling associated with the introduction of adequate controls for both family background and ability measures. Moreover Behrman (1990) finds compelling evidence in a number of poorer countries that failure to account for covarying family, ability, and other traits imparts a significant upward bias to estimates of the economic returns to schooling. None of these studies, however, suggests that the economic returns to schooling, properly estimated, are nonexistent.

${ }^{20}$ Heckman et al. (1996), for example, identify statistically significant credentialing effects, but the economic return to years of schooling per se remains substantial even accounting for these effects.

${ }^{21}$ These results control for family background, aptitude, and participation in an academic program and are invariant to the use of OLS, OLS fixed effects, or instrumental variable estimation.
} 
their teaching of the kinds of mental capacities required in employment. The most direct test of the proposition that the contribution of schooling to the development of cognitive skills accounts for the effect of schooling on earnings is to ask if earnings covary with years of schooling in populations that are homogeneous with respect to level of cognitive skill. A positive answer in a well-specified model suggests that schools contribute to earnings by means other than their contribution to cognitive skill.

An approximation of this test is available. Suppose that the income-generating structure for a given demographic group is

$$
y=\beta_{s} s+\beta_{b} b+\beta_{c} c+\epsilon
$$

where $y, s, b$, and $c$ measure earnings, schooling, parental socioeconomic background, and cognitive skill level, and $\epsilon$ measures stochastic influences on earnings uncorrelated with the other explanatory variables. Many estimates lack measures of cognitive skill and hence estimate

$$
y=\beta_{s}^{\prime} s+\beta_{b}^{\prime} b+\epsilon^{\prime},
$$

with $\epsilon^{\prime}$ representing the stochastic influences as above plus the influences of cognitive skill operating independently of demographic grouping, socioeconomic background and schooling. We can compare two estimated regression coefficients for a years-of-schooling variable, one in an equation like (4) in which a measure of cognitive skill also appears $\left(\beta_{s}\right)$ and another like (5) in which the cognitive measure is absent $\left(\beta_{s}^{\prime}\right)$. The ratio of the first to the second, which we write as

$$
\alpha=\frac{\beta_{s}}{\beta_{s}^{\prime}},
$$

is an estimate of the contribution of traits other than those measured on the cognitive tests to the estimated return to schooling (Gintis 1971). We call this the "noncognitive component of the returns to schooling." Figure 3 illustrates our logic. We will consider shortly the possibility other cognitive capacities not captured on existing tests might give a different result.

If schooling affected earnings solely through its contribution to cognitive capacities (assuming these to be adequately measured by the test scores used), $\alpha$ would be zero, because the regression coefficient of years of schooling would fall to zero once the cognitive level of the individual is accounted for, there being (by hypothesis) no contribution of schooling to earnings beyond its effect on cognitive functioning. By contrast, if the contribution of schooling to cognitive skill explained none of schooling's contribution to earnings, $\alpha$ would be unity. The estimates involved are 


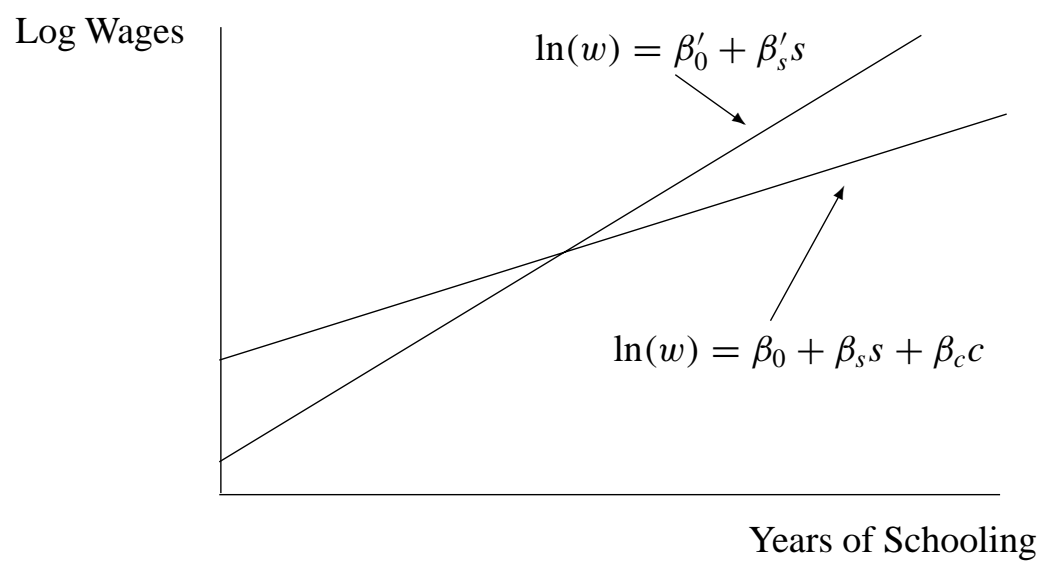

Figure 3: Estimating the Non-Cognitive Component, $\alpha=b_{s} / \beta_{s}^{\prime}$, in the Returns to Schooling

of course subject to biases, and we address this question at some length in Appendix 2 (available from authors). The most obvious potential problem-that the cognitive score might be measured with considerably more error than the schooling variable and hence $\alpha$ is upward biased-is almost certainly not the case.

For the United States over the period from the late 1950s to the early 1990s, we have been able to locate 25 studies allowing 58 estimates of the relationship between $b_{s}$ and $b_{s}^{\prime}$ and thus an estimate of $\alpha$. The data sources underlying this and the other figures in this paper are described in Appendix 1. Methods of estimation differ of course, and the demographic groups covered and the years for which the data apply vary considerably. We have surveyed these studies and selected what we considered to be the best specified estimates in each study. For example, we favored estimates using measurement error correction and instrumental variables estimation or other techniques to take account of endogeneity of the explanatory variables. We have included all studies available to us. ${ }^{22}$

The mean value of $\alpha$ in our studies is 0.82 , meaning that introducing a measure of cognitive performance into an equation using educational attainment to predict earnings reduces the coefficient of years of education by an average of 18 per cent. The median for $\alpha$ was 0.84 , and the range was 0.48 to 1.13 . This suggests that a substantial portion of the returns to schooling are generated by effects or correlates of schooling substantially unrelated to the cognitive capacities measured on the

\footnotetext{
${ }^{22}$ We have located 5 additional studies, allowing an additional six estimates, where the dependent variable is a measure of occupational status rather than earnings: Bajema (1968), Conslisk (1971), Duncan (1968), Sewell, Haller and Ohlendorf (1970), and Porter(1974). The mean value of $\alpha$ in these studies is 0.89 , and the lowest is 0.81 . These results are not reported in Figure 4.
} 


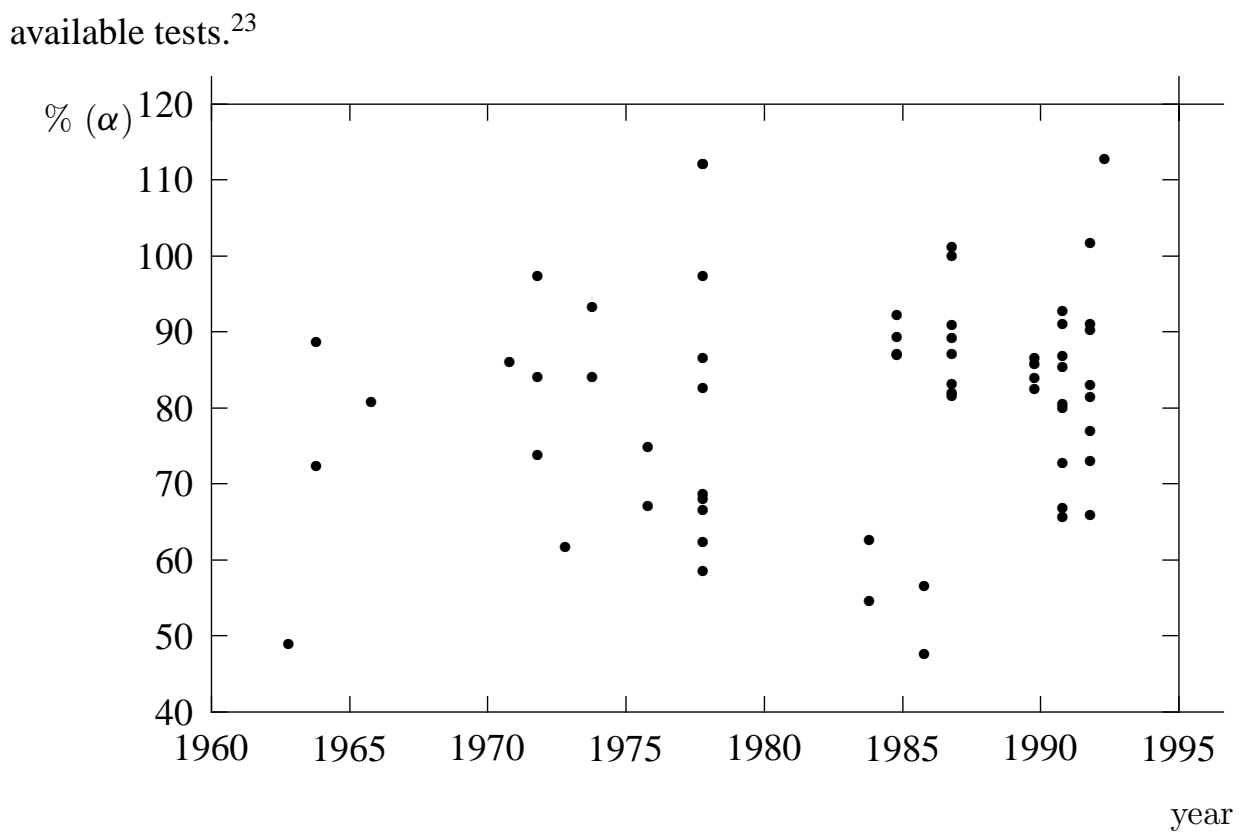

Figure 4: The Noncognitive Component Fraction, $\alpha$, of the Private Return to Schooling over Time: A Summary of Fifty Eight Estimates from Twenty Five Studies

In Figure 4 we present these data, along with the years to which the earnings data pertain. In a regression using categorical variables to take account of the demographic groups studied, there is no statistically significant time trend in the noncognitive component of the return to schooling. This evidence supports the conclusion that the role of measured cognitive traits in the contribution of schooling to earnings has not increased over the past three decades. Because 24 estimates by a single author, Min-Hsiung Huang, constitute a substantial fraction of our total, we tested the data for a time trend with the Huang estimates removed, and found none.

A single study covering the years 1974 to 1994, uses the same cognitive test as well as earnings and schooling measures across time and thus allows a less noisy assessment of the secular movement of $\alpha$. Huang (1996, see also Robert Hauser

\footnotetext{
23 These data concern the United States alone, and we do not draw any inference from them about the returns to schooling in other economies. We suspect, and there is some evidence (Boissière, Knight and Sabot 1985, Alderman, Behrman, Ross and Sabot 1996, Glewwe 1996, Lavy, Spratt and Leboucher 1997) that in societies where schooling is more limited in its scope, the cognitive component in the returns to schooling may be considerably larger than in the United States. However according to Moll (1995), in a sample of black workers in South Africa, the value of $\alpha$ for returns to primary schooling is 0.73 , for secondary schooling it is 0.67 , while for higher education the value is 0.92. These are well within the range of estimates presented in Figure 4.
} 
and Huang 1997) presents estimates, based on the General Social Survey, of the returns to schooling among eight demographic groups using appropriate measures of family background as co-predictors of the logarithm of earnings. The mean estimates of $\alpha$ are: 0.86 for $1974-1982,0.90$ for $1984-1989$, and 0.83 for 1990 1994. There appears to be no tendency for the measured cognitive component in the returns to schooling to increase over time in these data. The strength of the Huang study is that it uses the same test over a very long period of time. Shortcomings include the brief and limited nature of the cognitive test (a short vocabulary test). ${ }^{24}$ However we do not think that Huang's results are attributable to problems with the cognitive measure. Christopher Taber (1997):22, using a much more adequate set of test scores (four subsections of the Armed Services Vocational Aptitude BatteryGeneral Science, Word Knowledge, Auto and Shop Information, and Mathematics Knowledge) in estimating the returns to college completion for white males in the National Longitudinal Study of Youth (NLSY) in 1982-4, 1985-7 and 1988-90, reports data allowing calculation of the following values of $\alpha$ for these years: 0.65 , 0.71 , and 0.82 .

These data suggest that a major portion of the effect of schooling on earnings operates in ways independent of the contribution of schooling to measured cognitive functioning. Correspondingly the contribution of cognitive functioning to earnings is substantially independent of schooling. This being the case, it might be thought that cognitive scores might explain a substantial fraction of the residual variance in the standard earnings equation, that is one including years of schooling but not cognitive scores. But this is not the case.

Consider equations (4) and (5) above. Where studies have estimated both of the above equations we can use

$$
\Delta R^{2}=\frac{\sigma_{\epsilon^{\prime}}^{2}-\sigma_{\epsilon}^{2}}{\sigma_{y}^{2}}
$$

as a measure of the amount of residual variance of earnings explained by variation in cognitive score. We have located 57 of these estimates in 24 studies. The estimated values of $\Delta R^{2}$ (using in most cases 'corrected' $R^{2}$ ) along with the years to which the earnings data pertain appear in Figure 5. The mean value of $\Delta R^{2}$ is 0.0104 , the median is 0.007 and the range is -0.15 to 0.04 . Regressing the estimates of

\footnotetext{
${ }^{24}$ Vocabulary tests have been shown to be highly correlated with more general IQ tests. Miner (1957) found a median correlation of 0.83 between vocabulary tests and IQ scores from 36 studies. The main problem with the GSS vocabulary test is its brevity, which contributes to a large error variance in the scores. All of the estimates from Huang (1996) and Hauser and Huang (1997) used in our analysis are corrected for measurement error. The correlation between the GSS cognitive score and a more adequate IQ measure (from the Wechsler Adult Intelligence Scale), corrected for measurement error, is about 0.6.
} 
$\Delta R^{2}$ on the years to which they pertain, we find no time trend in its value. ${ }^{25}$ This result is robust to correcting for time trends in the demographic characteristics of the groups covered by the studies, and whether the estimate is based on the NLSY, the General Social Survey (GSS), or other data sources. There is reason to believe that these estimates may be downward-biased, due to the heavy reliance on samples of relatively young workers. The reason is that individuals with greater cognitive skill are likely to engage in more training early in life, and thus to have steeper earnings age profiles than those with less cognitive skill. Thus studies using younger workers probably understate the lifetime labor market returns to cognitive skill. But restricting ourselves to data sets using individuals in their thirties or older do not appreciably alter the estimates. In their careful study of the contribution of measured cognitive ability to explaining residual wage variance, Cawley, Conneely, Heckman and Vytlacil (1998) conclude:

If there exists some ' $\mathrm{X}$ factor' that can explain the large residuals common in wage equations, it is not measured cognitive ability.

The fact that measured cognitive skills explain very little of the residual variance in earnings does not mean that cognitive skills are unimportant, but only that they add little explanatory power to an account of earnings differences based on the usual schooling, socioeconomic background, and demographic variables. This is true because if measures of cognitive functioning are highly correlated with other regressors, much of the effect of cognitive skills on earnings will be picked up by these regressors. We therefore turn to the importance of cognitive skills as determinants of the distribution of earnings. Our final question, whether cognitive skill is increasingly important as a determinant of the distribution of earnings, is more difficult to assess on the basis of available studies. The relevant statistic is the change over time in the magnitude of a suitably normalized regression coefficient for the cognitive score in a well-specified earnings or income generating equation similar to (4). Cognitive functioning may be an important determinant of earnings for two distinct reasons: cognitive skills may be rewarded in the labor market, and independently of that, cognitive skills may predict higher levels of schooling attainment, and contribute to subsequent earnings by this route. Because we are interested in labor market rewards to cognitive skills we want to estimate the direct effect on earnings of variations in cognitive performance per se, not the indirect effects operating via the effect of cognitive score the level of schooling attained, along with the returns to schooling. Three problems arise.

\footnotetext{
${ }^{25}$ Correcting for measurement error in the relevant cognitive score (e.g., Huang 1996) or for the possibly multifaceted nature of cognitive skill (e.g., Cawley et al. 1997) have little effect on these estimates. There is also a possible downward bias in the time trend due the fact that later studies tend to use more regressors. We are unable to assess the extent of this bias.
} 


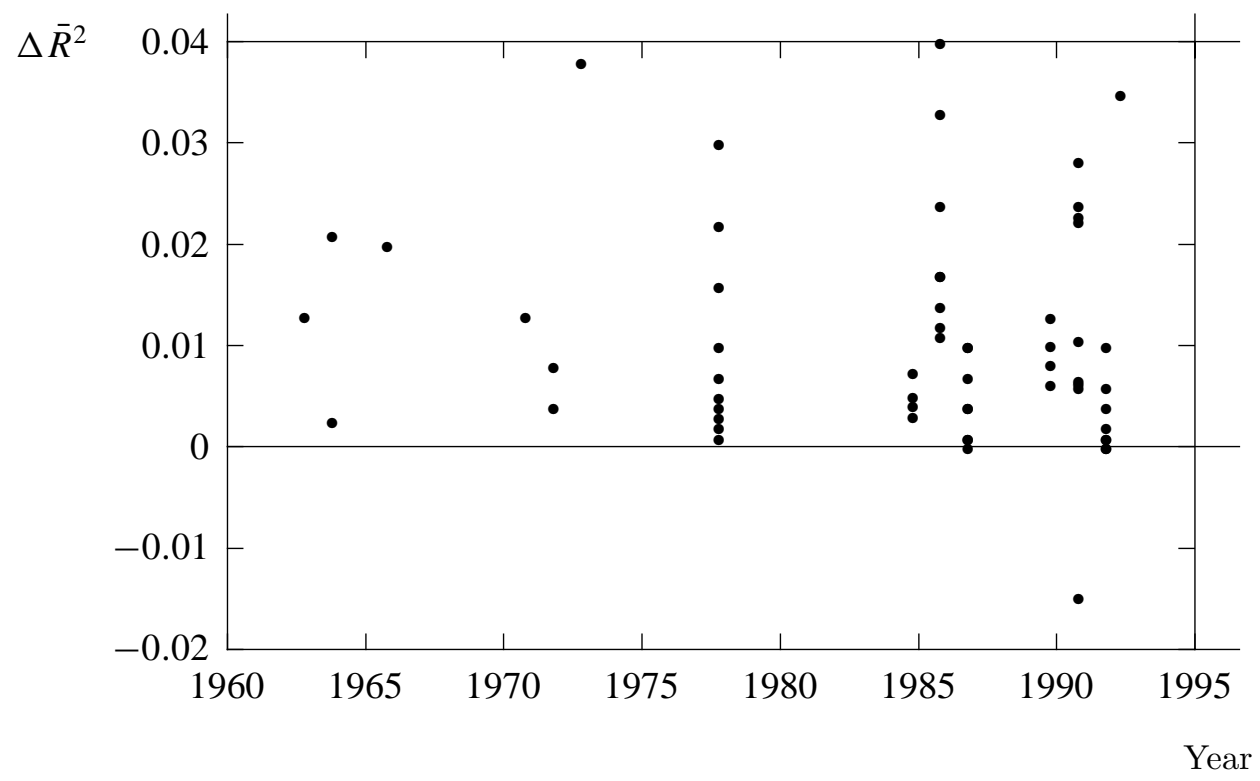

Figure 5: The Contribution of Cognitive Differences to Residual Inequality by Year: Estimates from 57 Estimates in Twenty Four Studies. $\Delta \bar{R}^{2}$ is the change in adjusted $R^{2}$ when a cognitive test is added to the regression.

First, it is not clear how the relevant estimates should be normalized. The two obvious candidates represent answers to different questions: we might want to know the effect of a unit change in cognitive ability on labor market success expressed either in units of percentage change in earnings or in standard deviation units of the distribution of earnings. Thus the coefficient of the cognitive measure in a log earnings equation gives us the effect on the level of income relative to mean incomes, while the normalized regression coefficient gives us the effect on income in units based on the distribution, rather than the level, of earnings. ${ }^{26}$ The former measures the effect of a unit increase in the cognitive score on earnings, and is hence a plausible measure of the scarcity of cognitive skill. The latter, normalized on the distribution of earnings, measures the importance of the distribution of cognitive

\footnotetext{
${ }^{26}$ If the relationship between the standard deviation of the income measure and its mean does not change much, these two measures will not differ appreciably. But we know this has not been the case. Indeed, it is precisely the increase in the coefficient of variation of income that has motivated renewed interest in the determinants of income. This being the case, we cannot infer from the lack of a time trend in the normalized regression coefficient $\beta_{c}$ that there has been no time trend in the regression coefficient itself $\left(b_{c}\right)$. This is because $\beta_{c}=b_{c} \sigma_{c} / \sigma_{y}$ and $\dot{\beta}_{c}$ is therefore just $\dot{b}_{c}+\dot{\sigma}_{c}-\dot{\sigma}_{y}$. If the variance of the test scores is relatively unchanging, the rate of change of the normalized regression coefficient is approximately equal to the rate of change of the regression coefficient minus the rate of change of the standard deviation of log earnings.
} 
skills as a determinant of the distribution of earnings. Indeed, the square of the normalized regression coefficient is simply the direct contribution of the distribution of cognitive skills to the variance of the logarithm of earnings. These two measures need not move in the same direction, as an increase in the labor market scarcity of cognitive skill $b_{c}$ could be associated with a decline in the normalized regression coefficient $\beta_{c}$ if the variance of the earnings measure is rising rapidly. ${ }^{27}$ We present estimates of the normalized regression coefficients $\left(\beta_{c}\right)$ as well as estimates of the derivative of the logarithm of the wage with respect to a normalized test score, $\beta_{c^{\prime}}$, measuring the percentage change in the wage associated with a standard deviation change in the test score. ${ }^{28}$

Second, formidable econometric problems confront any attempt to identify a time trend in the returns to cognitive performance. This is due in part to the fact that cognitive performance and educational attainment are highly sorted, and while it is clear that the returns to well educated high cognitive performers have risen in recent years it is difficult to disentangle the separate effects (Cawley, Heckman, Lochner and Vytlacil 2000). Moreover, as Cawley et al. point out,it is very difficult to estimate the impact of the passage of time independently of the effect of the ageing of the individuals under study, particularly given that there is little reason to believe that the relationship between cognitive level and post-school human investments mentioned above remains constant over time.

A third problem is that we have few strictly comparable studies widely separated in time. A short time frame may be misleading if our interest is in long-term changes in inequality. Richard Murnane, John Willett, and Frank Levy's (1995) careful study using two large surveys refers to earnings in 1978 and 1986. They find substantial increases over this eight year period in the estimated coefficient of a mathematics score in predicting the log of hourly wages. ${ }^{29}$

${ }^{27}$ This comes from the following reasoning. If

$$
y=\sum_{1}^{n} \beta_{i} x_{i}
$$

then

$$
\sigma_{y}^{2}=\sum_{i, j} \beta_{i} \beta_{j} r_{i j},
$$

where $r_{i j}$ is the correlation between $x_{i}$ and $x_{j}$. Since $r_{i i}=1$, the direct contribution of $x_{i}$ to the variance of $y$ is then $\beta_{i}^{2}$.

${ }^{28}$ From the previous footnote it can be seen that

$$
\beta_{c^{\prime}} \equiv b_{c} \sigma_{c}=\beta_{c} \sigma_{y}
$$

${ }^{29}$ Grogger and Eide (1995) using the same data set and the same math score obtain a similar result. 
However Hauser and Huang's (1997) estimates based on the General Social Survey and using the unstandardized regression coefficients of a given test score on the natural log of earnings for black and white men and women of various ages over the period 1974-1994 led them to conclude (p. 363): "we again find no evidence of systematic increase in the effects of verbal ability on earnings." While the shortcomings of the GSS verbal test may impart a downward bias in their estimates for all years, it is difficult to see how it could have masked an upward trend in the importance of the cognitive traits measured on the test.

Bishop (1991) found that for both men an women in the NLSY the appearance of increasing wage effects of cognitive test scores over the period 1981-1986 was due entirely to the covariation of the scores and levels of schooling. In earnings equations including both schooling and cognitive performance, similar to equation (4), Bishop found a strong time trend in the wage effects of schooling and no time trend in the wage effects of a variety of cognitive scores. ${ }^{30}$

In Figure 6 we present the 65 estimates from 24 studies that we have located that present or allow the calculation of the normalized regression coefficient $\beta_{c}$ for a cognitive measure in an earnings equation. The mean of these estimates of $\beta_{c}$ is 0.15 , the median is also 0.14 , and the range is -0.09 to 0.33 . For purposes of comparison, the mean and median estimate of the normalized regression coefficient of years of schooling $\beta_{s}$ in these studies is 0.22 using the second normalization. The mean estimate of $\beta_{c^{\prime}}$ is 0.07 and the median is 0.08 , suggesting that a standard deviation difference in cognitive performance is associated with something less than a ten percent increase in wages, and is in this respect roughly equivalent to a year of schooling.

In a regression of these estimates on time alone, on time and categorical variables

Cawley et al. (2000) provide a detailed review of the available studies which they conclude yield "mixed results on the economic returns to ability over time."(p. 235)

${ }^{30}$ Blackburn and Neumark (1993) report no statistically significant time trend in the coefficient of ability, but find a positive trend in the ability/education interaction. Using both the AFQT and a heterogeneous set of IQ (and achievement) test scores, Jencks and Phillips estimate a log earnings function that does not condition on years of schooling. They find an increasing return to a cognitive score between 1983 and 1993. However because they do not include years of schooling as an earnings predictor, it is impossible to say whether their result measures an increased return to schooling or to cognitive performance per se. However, Christopher Taber (1997), also using the NLSY (and the AFQT), estimates distinct time trends in the private return to both higher education and to cognitive performance and finds no evidence of an increased earnings effect of the cognitive score for white males between 1979-1991. Comparing the covariation of AFQT scores and earnings in black men in the years 1964 and 1980 Jencks and Phillips (1998) find that the cognitive score is a stronger predictor of earnings in the latter year. But as in their study just mentioned, these estimates do not condition on the years of schooling, so one cannot tell if these are labor market returns to cognitive skill or a change in the effect of cognitive skill on schooling attainment and or an increase in the rate of return to schooling for individuals of identical cognitive skill. 
measuring the age, race, and sex of the subjects, the time trend was very small and insignificant. A consideration of all of the available evidence would caution against the conclusion of any trend.

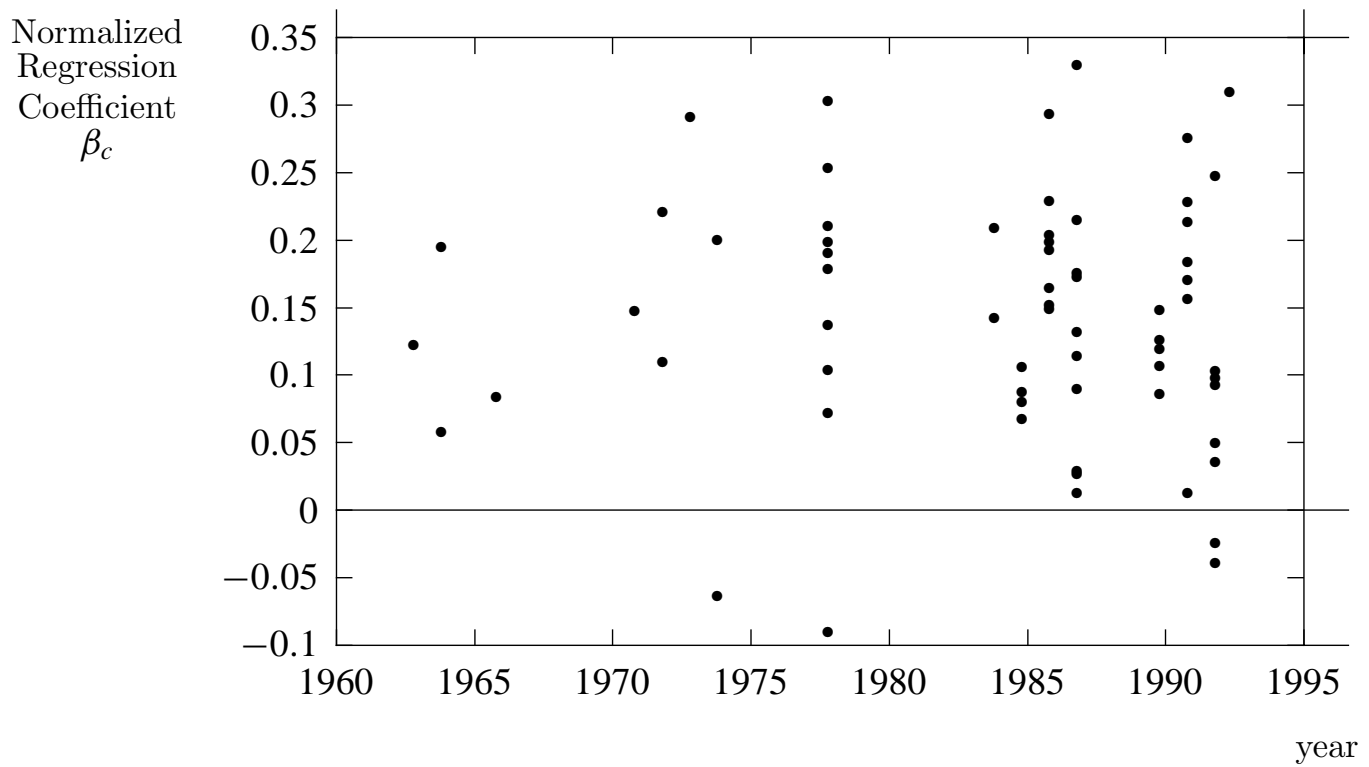

Figure 6: Normalized Regression Coefficient $\beta_{c}$ Of Cognitive Score on the Logarithm of Income or Earnings by Year: Sixty Five Estimates from Twenty Four Studies

An exception is for the sixteen estimates using African American respondents, there is a strong upward trend in the estimated coefficient of cognitive performance. The trend is due to quite low estimates for four studies between 1958 and 1964.

We investigated the sensitivity of the results reported in Figures 4-6 to a number of possible sources of error. ${ }^{31}$ First, we tested for effects of the age at which the test was taken and especially whether the respondent had completed schooling at the time. For about two thirds of the estimates we were able to determine if the test was taken before or after school completion. For these estimates there no effect of the timing of the test on any of the four measures-the three shown in Figures 46 plus the alternative normalization of the regression coefficient of the cognitive score. Second, we investigated the importance of the type of test used, and found that studies using more comprehensive tests generally performed somewhat less well than those using more narrowly defined tests (often components of the more comprehensive test). However, the estimated effects were not even marginally significant ( $t$-statistics less than unity) except for the estimate of $\alpha$, the contribution

\footnotetext{
${ }^{31} \mathrm{~A}$ more complete report of these sensitivity tests is available from Osborne.
} 
of noncognitive traits to the returns to schooling. Here the more comprehensive tests yielded estimates about ten percent larger than the narrower tests.

Third, for none of the outcomes measured did the elimination of the largest single study (Huang 1996) alter the results concerning cognitive performance in any substantial way, though Huang's estimates of the returns to schooling exceed the others by a significant amount. Finally our inability to reject the null hypothesis of no positive time trend in the data (other than for African Americans) pertains not only to the entire set of data, but partitions of it created by taking account of the timing and nature of the cognitive test.

Our conclusion is that while both cognitive functioning and schooling are important determinants of earnings, (i) the economic return to schooling is not accounted for primarily by its contribution to enhanced cognitive scores, (ii) differences in cognitive scores account for very little of the residual earnings variance, and (iii) these data provide no support for the hypothesis that the effect of cognitive scores on earnings increased secularly over the four decades covered by our estimates.

\section{The Role of Cognitive Skills in Production}

For the following reasons, the above evidence does not imply that cognitive skills are unimportant as determinants of labor market success or as inputs into the production process.

First, the estimated coefficient of a cognitive score in an earnings equation is at most a measure of the scarcity of the measured skill, as indicated by its marginal product at the current level of use of this input. This coefficient thus says nothing about the contribution of cognitive skills to production in general, as would be indicated by a production function. Modest contributions of cognitive performance to earnings determination in the United States are thus consistent with more substantial contributions in economies in which cognitive skill is less abundant. ${ }^{32}$ In the advanced economies, even quite skill-biased technical change and shifts in employment to more cognitively demanding occupations and sectors may be offset by the dramatic increase in the supply of cognitive skill recently documented for the United States, the United Kingdom, the Netherlands, and elsewhere-termed the Flynn Effect (Flynn 2000).

Second, there are aspects of cognitive functioning not measured on the tests available in the large data sets used above. In smaller data sets, measures of cognitive functioning substantially independent of the more common tests scores have been strong predictors of occupational proficiency (Sternberg, Wagner, Williams and Horvath 1995). For example, the Tacit Knowledge Inventory, which is virtu-

\footnotetext{
${ }^{32}$ See, for example, the studies referred to in footnote 23.
} 
ally uncorrelated with IQ test scores, exhibits substantial correlations with business success (salary, "generating new business for the bank") and more than doubles the explained variance (to 0.57 ) when added to an IQ score when predicting managerial success in two problem solving tasks (Sternberg et al. 1995). The same measure added 5 percentage points to the explained variance in a managerial compensation equation which accounted for age, experience and schooling (Williams and Sternberg 1995).

The success of particular measures like the Tacit Knowledge Inventory in small surveys should be considered in light of the limited predictive success (in samples representative of the working population as a whole) of vocationally oriented cognitive tests, among which is the Armed Services Vocational Aptitude Battery, from which the AFQT is taken. Given the considerable variety of cognitive tests that have been in use over the past half century, and the interest in expanding the range of cognitive capacities captured on test instruments dating at least as far back as Edward Thorndike's (1919) advocacy of the concept of "social intelligence"-which he termed the ability to manage people and act wisely in social situations-it would be surprising if a general test of cognitive functioning were to alter significantly the conclusions of our survey.

Third, while we are thus skeptical of the view that as yet unmeasured general cognitive skills will be found to be strong predictors of earnings, it is likely that cognitive skills specific to particular tasks and classes of work are essential to successful job performance. Because jobs differ with respect to their cognitive demands, this "specific cognitive skills hypothesis" is worth exploring. We know, for example that performance on a general cognitive test has over twice the validity in predicting job proficiency among manufacturing workers performing tasks involving setup as opposed to either feeding or off-bearing a machine (Hunter 1986).

Studies of particular occupations allow us to explore these issues, but raise a number of interpretive difficulties, the most important being the measure of job performance. We are interested in the determinants of earnings, taking account of the fact that for reasons of motivation, attitude and the like, earnings and ability to do the job may be quite weakly related. Thus we are more interested in measures such as supervisor ratings, which may be more closely related to pay, rather than measures such as work samples, which psychometricians term "maximum performance tests" because they only show how well the individual can perform, and which may have little relationship to typical performance on the job (Guion 1983).

We begin with the question: are there job specific cognitive abilities measured by subsets of test items in general cognitive tests, and how well do these, when properly weighted, predict supervisor ratings or directly measured job performance? John Hunter (1986) described a research strategy to address this question: 
Multiple regression offered an optimal procedure for combining test scores...instead of scoring tests to create one score for general cognitive ability, we might combine tests scores with different weights for different jobs...to...increase predictive validity. (p. 355)

Based on his survey of sixty-five years of empirical research he concluded:

A massive data base gathered by the United States Employment Service and even more data gathered by the United States military have shown the specific aptitude hypothesis to be false. (p. 358)...Only very meager gains are made by considering cognitive aptitudes above and beyond the measurement of general cognitive ability. Furthermore, there is only a handful of jobs were there is any gain at all. (p. 355).

Using direct job performance tests for seven military positions (e.g., air traffic controller, jet engine mechanic) Ree, Earles and Teachout (1994) reach the same conclusion, though for two of the seven jobs studied-aerospace ground equipment mechanic and information systems radio operator-job specific aptitudes substantially improve the prediction of job performance.

It does appear, however, that job specific knowledge has an important influence on supervisor ratings. Hunter's (1986) survey of 828 military and 525 civilian studies of job performance in particular occupational tasks finds a mean simple correlation between a measure of general ability and supervisor rankings of 0.24 and 0.47 respectively. ${ }^{33}$ In both cases less than a third of this correlation is due to the covariation of the cognitive test with a direct measure of job performance, the rest being accounted for by the covariation of the cognitive score and a measure of knowledge specific to the particular job and the latter's substantial effect on supervisor ratings independently of job performance. Supervisor ratings are better predicted by what employees know about their jobs than by how well they can do them under test conditions. A subsequent meta-analysis (Schmidt and Hunter 1998) found that job knowledge tests predicted job performance about as well as general cognitive ability, and that in a multiple regression their respective normalized regression coefficients are 0.31 and 0.36, suggesting substantial independent

\footnotetext{
${ }^{33}$ Virtually all estimates are corrected for measurement error and restricted range. These estimates are consistent with the modest contribution of cognitive scores to the income determination process reported above. The job performance literature relies almost entirely on indices of validity, measured by simple correlations, while the economic literature tends to report a regression coefficient in a well-specified earnings equation reported above. The simple correlation between the logarithm of earnings and a cognitive score in data sets commonly used by economists is about 0.35 (Jencks 1979) which, when corrected for measurement errors in the two variables, taking account of both reporting errors, the transient component of income, and test-retest reliability in the cognitive score, yields a corrected correlation of 0.46 , or almost exactly Hunter's higher estimate (for civilian employment).
} 
influence of job knowledge. Examples of specific cognitive tests that predict job performance independently of general cognitive ability include a recently devised test for air traffic controllers (Durso 1999), and a clerical tasks aptitude test (Hunter 1986).

Finally, it may be that test scores overstate the importance of cognitive as a determinant of earnings. As with any task, test performance is influenced by things other than capabilities, and some of the determinants of test scores such as the extent of identification with the test giver or the degree of engagement in the task are not cognitive abilities at all. H. J. Eysenck (1994):9 writes:

Low problem solving in an IQ test is a measure of performance; personality may influence performance rather than abstract intellect, with measurable effects on the IQ. An IQ test lasts for up to 1 hour or more, and considerations of fatigue, vigilance, arousal, etc. may very well play a part.

The importance of the performance rather than capability aspect of the test score as a determinant of earnings is suggested by Bishop's (1991) finding that a measure of computational speed on time tested exams is a more robust predictor of earnings than two alternative measures - a normalized sum of academic tests as well as a measure of technical competence.

If test-taking effort affects performance and is correlated with socioeconomic status (SES), the cognitive abilities of lower SES individuals will be underpredicted by the test score. Arthur Jensen's (1968) summary of the psychometric evidence suggests that this may be the case. He writes: "In short, low SES children in the IQ range from 60-80 perform markedly better in those learning tasks [unrelated to previous schooling] than do middle-SES children in the same range of IQ. On the other hand low SES children who are above average in IQ do not show learning performance that is significantly different..." (p. 1332)

Because some of the non-cognitive determinants of cognitive test performance may also influence performance on the job and hence subsequent earnings, covariation of test scores and earnings may overstate the importance of cognitive abilities in the earnings generation process.

\section{The Ability to Benefit from Disequilibria}

In any economy, and particularly in a technologically dynamic economy, disequilibrium rents will make up some fraction of earnings and other factor payments. The ability of some individuals to recognize and act so as to benefit from and eventually dissipate these rents will generally improve the allocative efficiency of the 
economy. While efficiency-enhancing at the economy wide level, these abilities are not properly called 'productive skills,' as the traits in question may play no role in augmenting the labor input in a production function.

Schumpeter described 'leaders' and 'followers' as different personality types. What individual traits might contribute to one's capacity to occupy advantaged positions on the short side of non-clearing labor markets in disequilibrium, and to avoid the downward pressure on earnings associated with being on the long side? Consider the case of spatial disequilibria and the resulting importance of location as a predictor of the wage rate. ${ }^{34}$ Even within relatively competitive labor markets, like that of the United States, locational differences are considerable, and persist over long periods: in 1989, mean hourly wage rates (for White non-Hispanic individuals with given schooling, age, and sex) in California are about 50 per cent higher than in neighboring Nevada, with the New Jersey wage earners enjoying the same relative difference over similar individuals in nearby Maine. While some of these differences reflect differing local amenities including the cost of living, unmeasured characteristics of the wage earners and the like, the fact that one can predict interstate movements on the basis of estimated expected lifetime present value of the income benefits of moving suggests some of the differences reflect spatial disequilibria.

Some clues about the ability to benefit from disequilibria may be derived by looking more closely at the interstate wage difference data. Aba Schwartz (1971) used data on the ratio of net to gross migration rates to argue that the more highly educated are more "efficient" migrators. Our own analysis of 1989 interstate wage differences confirms that the variance of the natural logarithm of hourly wages among states for individuals of given age, schooling, and sex is significantly higher for the oldest age group, as would be expected, and declines significantly with level of schooling, confirming Schwartz' suggestion. More direct confirmation comes from estimates of using the present value of moving to predict migration. Bowles (1970) using interregional data for the United States in the late 1950s found that education contributed strongly and significantly to the responsiveness of potential migrants to spatial differences in income: for whites, the effect on expected migration rates of a $\$ 1000$ locational difference in the present value of expected income was twice as great for those with 16 years of schooling compared to those with 8 years.

Migration for higher pay has its downside counterpart in minimizing losses associated with displacement associated with plant closings and other negative shocks. Recent studies of displaced workers support the conclusions of the migration stud-

\footnotetext{
${ }^{34}$ Our data are from the United States 1990 Census of Population and Housing (SSTF22: Earnings and Occupation by Education).
} 
ies. Henry Farber (1996), using the Displaced Workers Survey of the CPS for the period 1981-1993, found that more educated workers suffer less earnings loss upon displacement than do the less well educated. Similarly Bruce Fallick (1993) found that higher levels of schooling contributed significantly to the probability of exiting from the state of post-displacement unemployment when the individual exited to a new industry, but not to the industry from which the worker had been displaced, suggesting that "education may do more to improve prospects in the new industry than in the old." (p. 317) (See also Elizabetta Magnani, 1997 and Cynthia Gustafson, 1998). The possibility that the effect of education on the ability to deal with disequilibria may go beyond what is learned in school is suggested by Rubinstein and Tsiddon (1999). They show that parental education predicts labor market success during recessions: controlling for own education, the impact of parental education on wages increases during downturns, and within each own education group, unemployment is much less cyclical among those with well educated parents. Parental income does not have these effects, so it is unlikely that parental education is capturing a wealth effect.

Why might the educated by more able to handle disequilibria? That handling disequilibria requires cognitive abilities enhanced through schooling (and for other reasons covarying with schooling) seems an obvious response, and one stressed by Welsh and Mark Rosenzweig (1995) in their treatment of disequilibrium effects of schooling. ${ }^{35}$ But we know of no data to support this for the case of migration. Philips Cutright (1974) found no evidence that higher AFQT contributed to a propensity to migrate. But this is hardly definitive, as it may be that the more cognitively able individuals are not more mobile but simply migrate in ways more effective in raising incomes. Another explanation may be that the educated are more future oriented. There is good evidence that individuals with higher incomes have lower rates of time preference (Green, Myerson, Lichtman, Rosen and Fry 1996, Hausman 1979) and education may be a contributor to this relationship as is suggested by Becker and Mulligan (1997).

A third possibility is that those who handle disequilibria well have developed distinct psychological orientations, such as "self-directedness." Similarly the ability to benefit from disequilibria may be enhanced by what social psychologists term an "internal" as opposed to an "external" locus of control, the latter being characterized by fatalism and a limited sense of personal efficacy (Andrisanni and Nestel

\footnotetext{
${ }^{35}$ Rosenzweig presents evidence, as does the previously cited paper by T. W. Schultz, that the returns to schooling are enhanced in agricultural populations exposed to rapid technical change. Rosenzweig reports that in a technically stagnant agricultural setting (in the Philippines) piece rate wages of harvesting labor was strongly related to the height of the worker but not to the level of schooling. Rosenzweig and his coauthors present related evidence on the ability of the more skilled to deal with novel situations (including the use of contraceptive devices).
} 
1976). By contrast to the "externals," the "internals... may search the labor market more carefully for job opportunities and better avail themselves of those that arise" and are more likely to engage in a "careful scanning and exploitation of job opportunities." (Andrisanni 1978b):105. Schooling appears to enhance levels of Kohn's measure of self directedness and to reduce a standard measure of "externality," the Rotter Scale. ${ }^{36}$ In the studies just cited, both psychological dimensions are significantly related to earnings (the Rotter scale inversely, as expected) at least on some specifications (both studies use longitudinal data sets to discriminate between the effects of economic success on internality and self direction as opposed to the reciprocal effect). ${ }^{37}$

We turn now to a consideration traits that might bear a competitive return not as a result of disequilibrium rents but in competitive equilibrium.

\section{Which Preferences are Incentive-Enhancing?}

We have shown that additional schooling raises individual earnings in ways that go beyond enhanced measured cognitive performance. With incomplete contracts governing the employment relationship, the relevant earnings-enhancing effects of schooling need not be skills in the conventional sense, but may be personal traits that, by attenuating the costs of endogenous contract enforcement, are valuable to the employer. Like cognitive skills, these incentive-enhancing preferences are scarce in equilibrium because they are costly to acquire, or for other reasons are limited in supply. Of course incentive-enhancing preferences need not be the effects of schooling and need not even be correlated with education, though as we will see there is some evidence for a covariation between incentive-enhancing preferences and schooling.

Research on the question has been limited by the fact that most nationally representative data sets linking earnings, schooling, and the personal characteristics of individuals do not include appropriate measures of behavioral traits. ${ }^{38}$

\footnotetext{
${ }^{36}$ Duncan and Morgan (1981) replicated the results concerning the Rotter score with mixed success. See also Goldsmith, Veum and Darity (1997).

${ }^{37}$ J. B. Rotter (1966) defines an internal locus of control as the degree to which an individual perceives success and failure as being dependent on one's own actions. The NLS in various years administered a Rotter Scale test instrument to its sample. Andrisanni and Nestel's study uses NLS data for the years 1969 and 1971 on middle aged males. See also Andrisanni (1977). An attempt to replicate Andrisanni's estimates by Duncan and Morgan (1981) using data from the Panel Study of Income Dynamics found large and highly significant effects of internality on the increase in hourly earnings over a four year period for whites (the normalized regression coefficient was 0.149) with similarly large but insignificant effects for blacks, and small and insignificant effects on wage changes over a two year period. Other evidence presented by Duncan and Morgan suggest that the estimated relationship between internality and wage growth is not robust.
} 
Empirical assessment of incentive-enhancing preferences and other earningsgenerating behavioral traits is also difficult in light of the strong likelihood that the traits influencing earnings will differ depending on the nature of the incentive problems arising from the underlying principal-agent relationship between employer and employee.

One set of empirical studies — on what social psychologists call 'Machiavellianism' or 'Machiavellian intelligence' (Richard Christie and Florence Geis 1970)_ suggests the context-dependent nature of the relationship between psychological traits and economic success. By Machiavellianism we mean behaviors that involve manipulating others in one's own interest and at a cost to others. Various measures of Machiavellianism have been developed. Subjects are typically asked to express agreement or disagreement with statements about manipulative behaviors. The 'Mach IV' scale by Christie uses statements by Nicolo Machiavelli (expressed in modern language) to elicit responses. 'Mach scores', as they are called, are substantially uncorrelated with measures of cognitive performance, political preference, psychopathology, or sex. High Mach scores are robust predictors of Machiavellian behavior in laboratory settings (Marvin Okanes and William Murray, 1980, Christie and Geis 1970).

Charles Turner and Daniel Martinez (1977) found that for those with higher levels of schooling, Mach scores covary significantly with income and occupational attainment, while with an inverse (and significant) relationship for less educated subjects. ${ }^{39}$ Clifford Schultz (1993) found that high Machs outperformed low Machs in loosely structured sales organizations (distinguished by fewer constraints on individual decision making) but that in tightly structured (hierarchical) organizations there were no significant differences in performance. Gable and Dangello (1994) find that sales managers' job performance (sales per square foot, gross margin return on inventory) is strongly predicted by measures of both Machiavellianism and locus of locus of control (fatalism) with multiple correlations, using both personality measures, of 0.46 and 0.56 for the two performance measures.

Four meta-analyses of personality measures as predictors of various objective and subjective indicators of job performance (Ghiselli and Barthol 1953, Tett, Jackson and Rothstein 1991, Barrick and Mount 1991, Schmidt and Hunter 1998) suggest that some dimensions of personality, particularly those captured on what are termed integrity tests and one of the "big five" personality traits, "conscientiousness"—are strong predictors of success in occupations. In the most recent meta-analysis these

\footnotetext{
${ }^{38}$ Exceptions include the presence of the Rotter scale in the National Longitudinal Survey, a range of behavioral and attitudinal variables in the Panel Study of Income Dynamics and the General Social Survey, and a rich array of psychological measures in the British National Child Development Survey.

${ }^{39}$ The relevant occupational attainment equations for men were estimated conditional on father's occupation, education, race, age, and the Mach score.
} 
two traits were found to be uncorrelated with general cognitive performance, with average normalized regression coefficients predicting job performance of 0.41 and 0.31 . The many individual studies we have consulted yield highly variable results, however. This is perhaps the result of the vast number of personality dimensions which may be measured, the fact that few of the studies explicitly attempt to derive the relevant personality trait measures from an analysis of the psychological demands of the job, and hence the lack of any persuasive account of which personality traits should matter in which jobs.

Notwithstanding the strong likelihood that the economic reward to particular incentive-enhancing preferences depends on the details of the employment situation, there is some evidence of general patterns of reward. Table 1 summarizes the large sample studies of the importance of personality and other noncognitive traits as determinants of earnings.

The survey of research by Jencks et al. (1979) makes it quite clear that personal traits- 'industriousness,' 'perseverance,' 'leadership,' and others-self-assessed and reported by others, as well as study habits and other behavioral patterns in school, influence subsequent occupational status attainment and earnings independently of parental socioeconomic background, cognitive test scores, and years of schooling. For example, in an equation predicting hourly earnings in a large representative sample, the normalized regression coefficient on a composite measure of noncognitive traits is four times the size of the analogous coefficient for a test score, twice that of family background, and 50 per cent larger than that for years of schooling. ${ }^{40}$

${ }^{40}$ Reported in Jencks et al. (1979), Table 5.8, equation 5. 
Table 1. Sample of Research on the Returns to Personality

\begin{tabular}{|c|c|c|c|c|c|}
\hline Study and Year & Dependent Variable & Psychological Variable(s) & $\begin{array}{l}\text { Statistically Significant } \\
\text { Results }^{a}\end{array}$ & Data & $\begin{array}{l}\text { Other } \\
\text { Regressors }^{n}\end{array}$ \\
\hline Andrisanni and Nestel (1976) & log wages 1969,1971 & Rotter (externality) & $-0.091,-0.092$ & $\mathrm{NLS}^{b}$ mature men & $\mathrm{S}, \mathrm{B}$ \\
\hline Andrisanni (1978a) & log wages 1971 & Rotter (externality) & -0.073 to $-0.154^{i}$ & NLS cohorts & $\mathrm{S}$ \\
\hline Duncan and Morgan (1981) & 4-year $\Delta \log$ wage & externality & -0.149 & $\operatorname{PSID}^{c}$ & $\mathrm{~S}$ \\
\hline Duncan and Dunifon (1998) & 1988-1992 log wages & motives, expectancies g & $0.07,0.14$ & PSID & $\mathrm{S}, \mathrm{T}, \mathrm{B}$ \\
\hline Filer (1981) & earnings 1967-1977 & $\begin{array}{l}\text { sociability, friendliness, } \\
\text { thoughtfulness, general activity }\end{array}$ & various $^{h}$ & $\begin{array}{l}\text { Psychological } \\
\text { Consultants Inc. }\end{array}$ & $\mathrm{S}, \mathrm{T}, \mathrm{B}$ \\
\hline Goldsmith et al. (1997) & log wage 1980 and 1987 & predicted self-esteem & $0.165,0.149$ & $\mathrm{NLSY}^{d}$ males & $\mathrm{S}, \mathrm{T}, \mathrm{B}$ \\
\hline Jencks (1979) & hourly wage & various $^{k}$ & beta sum 0.245 & Talent Survey & $\mathrm{S}, \mathrm{T}, \mathrm{B}$ \\
\hline Jencks (1979) & earnings & various $^{k}$ & 0.126 & Kalamazoo survey & $\mathrm{S}, \mathrm{T}, \mathrm{B}$ \\
\hline Murnane et al (1997) & log wage & self-esteem & $0.062^{m}$ & NLSY & $\mathrm{S}, \mathrm{T}$ \\
\hline Osborne (2000) & log earnings & rotter (externality) & -0.115 & NLSYW $^{e}$ & $\mathrm{~S}, \mathrm{~T}, \mathrm{~B}$ \\
\hline Osborne (2000) & log earnings & aggression, withdrawal & $-.116,-0.058$ & $\mathrm{NCDS}^{f}$ & $\mathrm{~S}, \mathrm{~T}, \mathrm{~B}$ \\
\hline
\end{tabular}

Notes: ${ }^{a}$ Normalized regression coefficients (beta coefficients) are presented unless otherwise noted. ${ }^{b}$ National Longitudinal Survey. Results from Andrisanni and Nestel are taken from Table A1 in the text. ${ }^{c}$ Panel Study of Income Dynamics. Results for Duncan and Morgan are taken from page 654. ${ }^{d}$ National Longitudinal Survey of Youth. The Goldsmith et al. results are found in Table 3 on page 825 of the text. ${ }^{e}$ National Longitudinal Survey of Young Women includes 5,159 young women ages 14-22 in 1968. ${ }^{f}$ National Child Development Survey of 18,060 children born in the UK during one week in March of $1958 .{ }^{g}$ Motives are dispositions to approach or avoid certain behaviors such as the need for challenge, power, and affiliation. Expectancies are similar to internality, an assessment of whether one's own actions will lead to successful attainment of a desired outcome. Results are from pages $33-34$ in the text. ${ }^{h}$ Information is not provided to produce beta coefficients. Regression coefficients for ascendancy, emotional stability, masculinity, sociability, thoughtfulness, friendliness, and general activity are found to be statistically significant at the 5 percent level. ${ }^{i}$ Results are taken from Tables 4.2, 4.3 and 4.4 in the Andrisanni text. By contrast, Duncan and Morgan (1981) find statistically significant results for only whites with a four-year change hourly earnings. Duncan and Morgan do not find statistically significant results for blacks with a two- or a four-year change, nor for whites with a two-year change in earnings. ${ }^{j}$ The results for Edwards are found in Table 6 on page 135 of the text. ${ }^{k}$ Information for the Talent survey is taken from Table 5.8 and psychological variables are, leadership, study habits, best work, leadership roles, never gone steady, academic reading, education necessary. The Kalamazoo study results are from Table A5.4 and personality traits include executive ability, industriousness, and perseverance.

${ }^{m}$ Normalized coefficients are found from Tables 1 and 3 in the text and additional regressions presented in the 1997 draft of this paper. ${ }^{n}$ Controls include schooling (S), intelligence tests (T), and background characteristics (B). All studies also include other regressors such as job tenure, age, or geographic location. 
A recent study (Greg Duncan and Rachel Dunifon, 1997) using the Panel Study of Income Dynamics (PSID) suggests robust effects of incentive-enhancing preferences. They study adult males whose motivational and behavioral traits had been measured 15 to 25 years prior to the observations of their current earnings. Among the motivational traits measured are preference for challenge over affiliation, fear of failure, sense of personal efficacy, and degree of trust. Behavioral measures included church attendance, participation in social clubs, television viewing, newspaper reading, and (as discussed in the Introduction) an interviewer's assessment of the cleanliness of the respondent's home. These variables along with a cognitive test score, a measure of years of schooling completed, and an unusually rich set of other controls were then used to predict the average of the log of hourly wages between 1988-1992. In separate regressions estimated by Duncan and Dunifon at the request of the present authors the following results were generated. First the reduction in unexplained variance associated with the introduction of the motivational and behavioral variables (to an equation including all background controls, schooling and the cognitive score) was 0.05 , a figure to be compared with the average of 0.01 for the reduction in unexplained variance associated with adding a cognitive score (in Figure 5). The introduction of the attitudinal and behavioral variables reduced the estimated coefficient on the years of schooling variable by 37 per cent, which may be compared with an average of a 18 per cent reduction in the schooling coefficient occasioned by the addition of a cognitive score (Figure 4).

In addition, another recent study (Osborne 2000) using the National Longitudinal Survey of Young Women (NLSYW) and the National Child Development Study (NCDS), finds behavioral traits to have a significant influence on the earnings of women, controlling for standard human capital variables. The Rotter locus of control is the only personality variable considered from the NLSYW. It is designed to measure the externality of an individual, or the degree to which they believe that outcomes are the result of luck or fate rather than hard work. The NLSYW collects measures of externality by using the eleven-item abbreviated Rotter scale, and measures of personal control, evaluated from four of these eleven questions, are used. From the NCDS, two orthogonal personality variables are extracted using principal components from a 146 item and 12-syndrome inventory of social adjustment evaluated when the respondents are eleven years of age. The inventory is evaluated during school by an outside investigator.

This study also addresses the two econometric issues most troubling in this literature, measurement error and the endogeneity of personality and outcome variables. Measurement error in each variable is corrected by augmenting the correlation matrix using reliability estimates from paired responses within the data set or external sources when the data does not allow. These reliability estimates allow "corrected" correlations to be used in regressions of wages on personality and hu- 
man capital variables. ${ }^{41}$ In addition, exogenous instruments for adult personality are developed, thereby preventing the overestimation of the coefficient on personality because of the positive covariance between personality and the error term. The first technique uses measures of personality prior to labor market experience as an exogenous instrument for adult personality and the second technique creates an instrument for adult personality that is independent of wages yet highly correlated with adult personality measures. The results appear in Table 2, with the estimated signs of variables from both data sets consistent with the literature for each country (Ashenfelter, Harmon and Oosterbeek 1999, Card 1995, Dearden, Machin and Reed 1997, Kerckhoff, Campbell and Trott 1982). ${ }^{42}{ }^{43}$ Column B of Table 2 presents the results incorporating an exogenous instrument for personality in the NLSYW human capital model. ${ }^{44}$ This instrument for adult personality is formed by purging the adult locus of control of the influence of past wages. The negative sign on the Rotter score indicates that externality - the belief that outcomes are the result of fate or luck-has a negative influence on earnings, with a one standard deviation increase in Rotter score associated with almost a seven percent decrease in wages. The coefficient is statistically significant and the results are similar to that found by Andrisanni (1978a) and Duncan and Dunifon (1998). Columns C and D present the results using the NCDS. The estimated coefficients on personality variables in column D are statistically significant and suggest that a one percent deviation change in aggression is associated with almost an eight percent decrease in wages and a one standard deviation increase in withdrawal is associated with over a three percent

\footnotetext{
${ }^{41}$ The exact process and reliability estimates are available in Osborne (2000).

${ }^{42}$ All regressions in Table 2 include a constant and are for white females actively employed in the year wages are measured. Dependent variable is the natural log of self-disclosed hourly wage with $t$-statistics in parenthesis. The coefficient $b^{\prime}$ represents the percentage change in wages from a one standard deviation change in the independent variable $\left(b_{x}^{\prime}=b_{x}\left(\sigma_{x}\right)\right)$. O Exams indicates the number of Ordinary Level Exams taken and is included here both as a measure of school quality and individual cognitive abilities.

Descriptive statistics are compared for the samples used with the full white sample of women in each data set to test for sample selection bias. Testing for differences in the means, the null hypothesis of equality cannot be rejected at the five-percent level for any variable of interest. In addition, from inspection of histograms, it is also clear that significant differences in the frequency distributions of any variable do not exist.

${ }^{43}$ Most of the literature estimates standardized coefficients on intelligence tests (e.g. AFQT) around 0.150, which is larger than estimated here. See Cawley, Conneely, Heckman and Vytlacil (1998), Murnane, Willett and Levy (1995), and Kane and Rouse (1995). When education is removed, the coefficient on measured intelligence increases dramatically and is statistically significant for both models.

${ }^{44}$ Results are also available using only women for whom a locus of control measure is available prior to work experience, assuring that the personality measure is exogenous to wages. These results however, are not significantly different from those using the instrumental variables approach discussed above.
} 
decrease in wages. In addition, the increase in the total explained variance of wages from including personality (0.014) is larger than the mean increase in explained variance from including cognitive scores to wage determination models reported above.

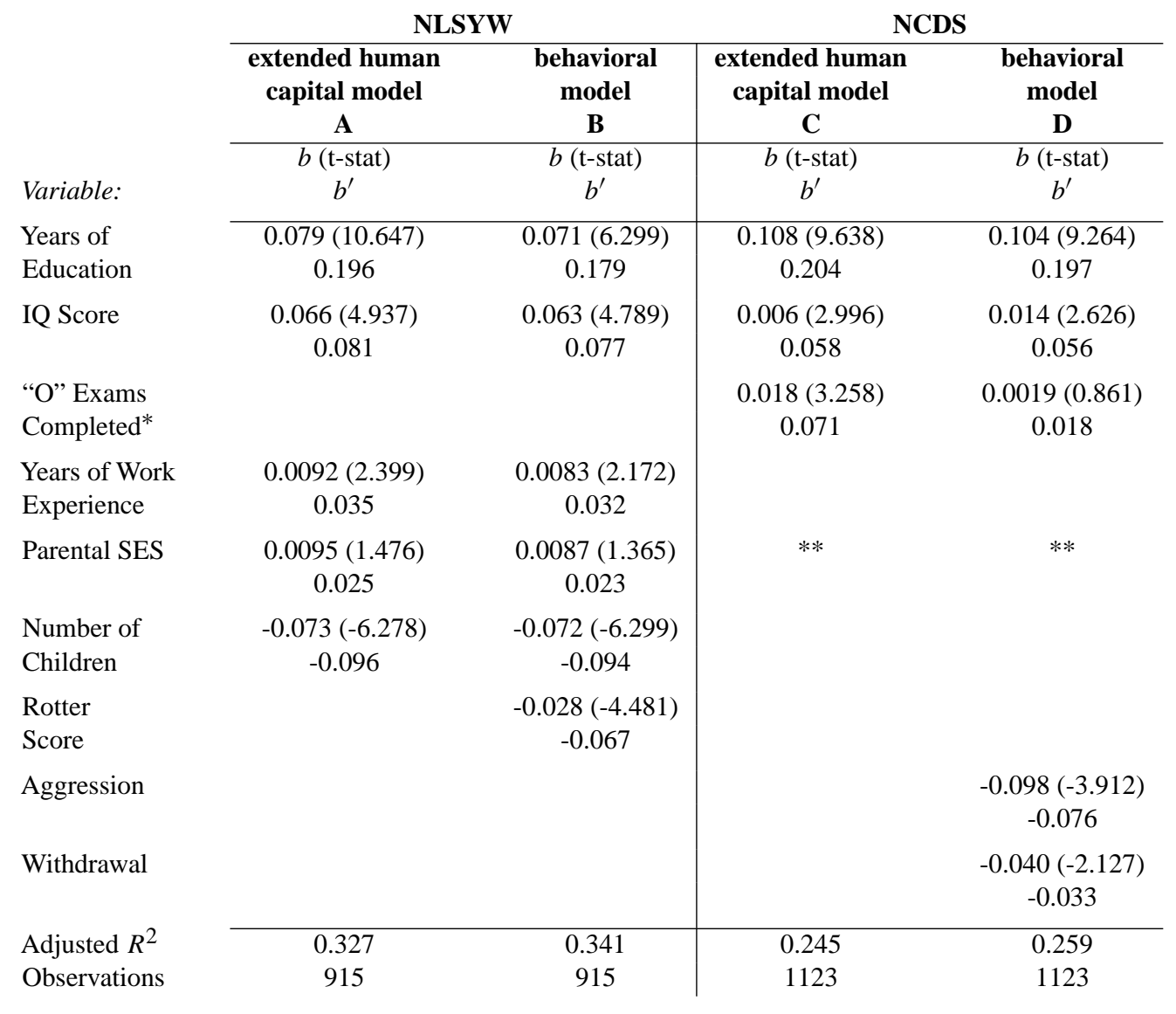

Table 2: Conventional and Behavioral Wage Equations

Notes: All regressions include a constant and are for white females actively employed in the year that wages are measured (from Osborne 2000).

* "O" level exams indicate the number of completed Ordinary Level Exams prior to age 21.

** Socioeconomic status is also included in the model however, is not reported here because it is not statistically significant in either model. 
Osborne (2000) also finds evidence of sex and occupational status differences in the returns to personality. The results are summarized in Table 3 below, and indicate that in high status occupations, women face significantly larger penalties than men for being aggressive while men are more heavily penalized for being withdrawn. Comparing values in the first "high status" column, a one standard deviation increase in aggression is associated with a decrease in women's earnings by more than seven percent while the same change is associated with an average increase in men's earnings by almost fifteen percent. Similarly a one standard deviation increase in withdrawal is associated with a decrease in men's wages by seventeen and fifteen percent for high and low status occupations, respectively. For women, these same changes in withdrawal are associated with a six percent increase in wages for high status women and a six percent decrease in wages for women in low status occupations.

\begin{tabular}{lcc|cc}
\hline & \multicolumn{2}{c}{ High Status } & \multicolumn{2}{c}{ Low Status } \\
\cline { 2 - 5 } & $\begin{array}{c}\text { Aggression } \\
\text { b (t-stat) } \\
\text { b' }\end{array}$ & $\begin{array}{c}\text { Withdrawal } \\
\text { b (t-stat) } \\
\text { b' }\end{array}$ & $\begin{array}{c}\text { Aggression } \\
\text { b (t-stat) } \\
\text { b' }\end{array}$ & $\begin{array}{c}\text { Withdrawal } \\
\text { b (t-stat) } \\
\text { b' }\end{array}$ \\
\hline \hline Men & $0.199(5.199)$ & $-.209(-6.196)$ & $-0.079(-4.599)$ & $-0.118(-8.375)$ \\
& 0.145 & -0.167 & -0.090 & -0.149 \\
Women & $-0.139(-3.023)$ & $0.098(2.578)$ & $-0.057(-1.216)$ & $-0.053(-1.354)$ \\
& -0.072 & 0.060 & -0.052 & -0.056 \\
\hline
\end{tabular}

Table 3: Returns to Distinct Personality Factors, Aggression and Withdrawal, by Sex and Predicted Occupational Status.

All regressions include a constant and are for white women actively employed in 1991 when wages are measured. The dependent variable is the natural $\log$ of self-disclosed hourly wages in 1991, when respondents were 33 years of age. The coefficient $b^{\prime}$ represents the percentage change in wages from a one standard deviation change in the independent variable $\left(b_{x}^{\prime}=b_{x} \sigma_{x}\right)$.

Thus, while the study of non-skill traits as earnings determinants is in its infancy, there is some evidence that motivational and behavioral traits are predictors of higher pay. It is impossible to know, of course whether these traits are simply proxies for (or perhaps contributors to the acquisition of) unmeasured skills or are valued as such by employers.

\section{Schooling, Behavior, and Earnings}

Schooling may affect earnings by either producing or signaling individual traits such as skills $(c)$ or incentive enhancing preferences $(b)$.The rate of return to schooling reflects both of these effects. We express earnings as $y=y(c(s), b(s) ; \ldots)$, where $s$ is a measure of schooling. School systems affect the "product mix" of cognitive 
skills, behavioral traits, and other individual traits of the students in their charge. Suppose for a given level of resources, a school can produce combinations of $c$ and $b$ indicated by the production possibility frontier as shown in Figure 7, which also presents an iso-earnings function derived from the earnings equation. A school system seeking to maximize a measure of scholastic achievement will select point $A$, while one choosing to maximize the subsequent earnings of students will select point $B$.

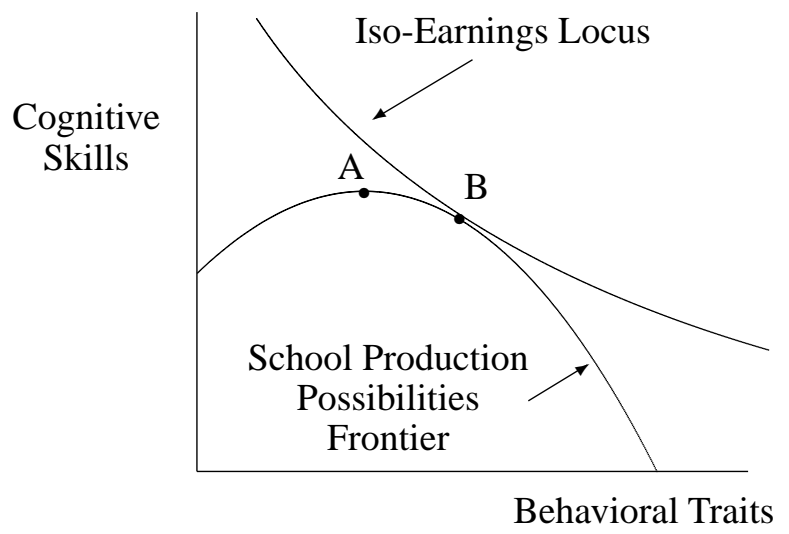

Figure 7: Maximizing Cognitive Skill vs. Earnings Capacity through Education

But is there any evidence that schools produce the incentive-enhancing preferences that distinguish 'good' from 'bad' workers? Glaeser and DiPasquale (1999) found large behavioral correlates of additional schooling, many of them plausible candidates for the behavioral traits in our $b$ vector. Moreover, Osborne's regressions for white women from the NLSYW indicate that controlling for child Rotter (age 7), measured IQ, and socioeconomic status, educational attainment has a statistically significant influence on the adult Rotter score. It seems unlikely, however, that the reduction of fatalism accomplished by schooling explains any significant portion of the rate of return to schooling. Introducing an adult Rotter score, purged of the effects of labor market experience, in an earnings equation reduces the estimated return to schooling by less than ten percent.

Little is known about how schools alter individual behaviors and personalities so as to "produce" good workers. A plausible hypothesis is that they do this by subjecting students to types of social interactions and systems of reward that replicate the social interactions and reward systems of the workplace, providing positive reinforcement for some behaviors and personalities and sanctions for others.

This interpretation is supported by a study of the reward system of schools which asked whether schools reward students who exhibit the specific personality traits 
valued by employers in the workplace. The study asked whether schools reward students who exhibit the specific traits valued by employers in the workplace. If true, we might reasonably infer that schools foster the development of these traits, and the economic return to schooling might represent payments to individuals with these traits. Richard Edwards (1976) used a peer rated set of personality measures of members of work groups in both private and public employment to predict supervisor ratings of these workers. In a parallel investigation with a distinct sample, Peter Meyer used the same peer-rated personality variables to predict grade point averages of students in a high school controlling for SAT (verbal and math) and IQ. Edwards found that being judged by their peers to be "perseverant", "dependable", "consistent", "punctual", "tactful", "identifies with work", and "empathizes" was positively correlated with supervisor ratings, while those judged to be "creative" and "independent" were ranked poorly by supervisors. Meyer found virtually identical results for the high school students in his grading study; independently of the student's cognitive level, Meyer's school rewarded with higher grades exactly the same traits that Edwards found to predict favorable supervisor ratings. ${ }^{45}$ Similarly, teachers and employers in these samples also penalize the same personality traits.

In light of our example of time preference, it is of interest to note that three peer-rated personality traits that are plausibly inversely related to time preference are statistically associated with both school and workplace rewards in the Edwards and Meyer studies. These are "defers gratification", "punctual" and "perseverant". While the first is most obviously germane, punctuality and perseverance may also reflect low rates of time preference. In equations predicting grades holding constant scores on three cognitive tests (in the high school sample) and predicting supervisor ratings (in the employee sample) the normalized regression coefficient for each of the three exceeds 0.30 .

We would like to know, of course, if schools produce the behavioral traits they reward. Recent studies of educational interventions outside the traditional classroom environment suggest that some programs have effectively reduced the criminal, disruptive, and other anti-social behaviors shown to predict reduced earnings. ${ }^{46}$ Some examples are shown in Table 4, which is drawn from Heckman (2000).

The Perry Preschool program, for instance, targeted disadvantaged four and five year olds, providing weekly home visits with parents and intensive preschool services for two years (Schweinhart, Barnes and Weikart 1993). When in their late 20's, participants exhibited substantially fewer arrests. The other early interventions described in Table 4 have been shown to be effective in reducing the antisocial behavior of children and adolescents (Lally, Mangione and Honig 1988, Donohue

\footnotetext{
${ }^{45}$ These results are reported in Bowles and Gintis (1976).

${ }^{46}$ The following material is based on Heckman (2000).
} 


\begin{tabular}{lll} 
Program & Program Description & Effects \\
\hline Houston PCDC** & $\begin{array}{l}\text { Home visits for parents } \\
\text { for 2 years; child nursery } \\
\text { care 4 days/week in year } 2 \\
\text { (Mexican Americans) }\end{array}$ & $\begin{array}{l}\text { rated less aggressive and } \\
\text { hostile by mothers } \\
\text { (ages 8-11) }\end{array}$ \\
$\begin{array}{l}\text { Perry Preschool Program** } \\
\text { (Schweinhart, Barnes }\end{array}$ & $\begin{array}{l}\text { Weekly visits with parents; } \\
\text { intensive preschool } \\
\text { Seikart, 1993) }\end{array}$ & $\begin{array}{l}2-3 \text { vs. 4-6 lifetime arrests } \\
\text { by age 27; 7\% vs. 35\% }\end{array}$ \\
$\begin{array}{l}\text { Syracuse University } \\
\text { Family Development } \\
\text { (Lally et al. 1988) }\end{array}$ & $\begin{array}{l}\text { Weekly home visits for } \\
\text { family; day care all year }\end{array}$ & $\begin{array}{l}\text { 6\% vs. 22\% had probation } \\
\text { files; offenses were } \\
\text { less severe }\end{array}$ \\
Yale Experiment & $\begin{array}{l}\text { Family support; home } \\
\text { visits and day care as } \\
\text { needed for 30 months }\end{array}$ & $\begin{array}{l}\text { Rated less aggressive and } \\
\text { pre-delinquent by teachers } \\
\text { and parents }\end{array}$
\end{tabular}

Table 4: The Effects of Early Intervention Programs on Behavior

and Siegelman 1998, Seitz 1990).

Interventions in adolescent years have also reduced rates of criminality. The Job Corps (Long, Mallar and Thorton 1981), for instance, provided seven months of education and vocational training for 16-21 year olds, reducing criminal behavior. The Quantum Opportunities Program (Taggart 1995) provided counselling, education, communications and development services to youth for four years beginning in ninth grade, considerably lowering the rate of criminal behavior and increasing high school graduation rates. For instance, 4 percent of the subjects were convicted of a crime in the two years following the program, as compared to 16 percent of a control group. The average number of arrests of subjects in this period was 0.28 as compared with 0.56 for the control group. The Big Brothers/Big Sisters (BB/BS) program (Tierney and Grossman 1995) provided youth with adult mentors. The authors found that 18 months later, the subjects (ages 11 to 17) were less likely to have initiated drug or alcohol use, to hit someone, to skip class or a day of school, or to lie to their parents, by comparison with a control group (see Table 5). They also had higher average grades and were more likely to feel competent in their school work and report a better relationship with their parents.

The above reasoning and evidence suggests that incentive-enhancing preferences and other earnings-relevant behavioral traits may be influenced by schooling, and may explain some of the economic returns to schooling, as well as other individual differences in earnings. 


\begin{tabular}{lr} 
& Change \\
\hline Initiating Drug Use & $-45.8 \%$ \\
Initiating Alcohol Use & $-27.4 \%$ \\
Number of Times Hit Someone & $-31.7 \%$ \\
Number of Times Stole Something & $-19.2 \%$ \\
Skipped Class & $-36.7 \%$ \\
Skipped Day of School & $-52.2 \%$ \\
Trust in Parent & $2.7 \%$ \\
Lying to Parent & $-36.6 \%$ \\
Peer Emotional Support & $2.3 \%$
\end{tabular}

Table 5: Benefits from Big Brother/Big Sister Mentoring Programs Source: Tierney and Grossman (1995).

\section{Conclusion}

It should be clear that much remains to be clarified concerning the relationship among behavior, skills, schooling, and earnings. Theoretical work in this area, by economists, psychologists and sociologists, should attempt to clarify the incentive structures of distinct types of workplaces and the ways that individual behavioral or psychological traits might affect employee responses. A second theoretical objective is to model market disequilibria as social environments in which individual behavioral or psychological traits may facilitate or preclude the capture of dise-

quilibrium rents. We suggest that future empirical research take a wider view of how individual characteristics impact on expected earnings and explore a variety of intervening variables between schooling and earnings. This should involve a cooperative research effort between psychologists, who have developed numerous stable and predictive measures of personal functions but tend to apply these measure to small samples and without regard for economic implications, and economists, who have little experience in creating measures of psychic functioning, but are accustomed to analyzing large data sets including psychological, demographic, and economic variables.

The measurement of the relevant behavioral traits and personality characteristics might be improved by greater emphasis on two approaches. First, because we are interested in situationally specific behaviors (rather than some intrinsic underlying characteristics of the individual) there is much to recommend the little-used peer rating method, which elicits perceptions of the individual's behavior from workor school-mates (referred to above in reference to the Edwards and Meyer studies). Second, we think that the implementation of simple behavioral experiments to subsamples of larger nationally representative samples may tap dimensions of per- 
sonality and behavior that have thus far eluded measurement. Examples include the employment and gift exchange experiments developed by Fehr and his coauthors.

What is it about individuals, then, that accounts for interpersonal differences in earnings? The puzzles with which we began made it clear that while cognitive performance, schooling, and parental economic status provide part of the statistical explanation, most of the individual differences in earnings remain unexplained by these conventional variables. Equally important, the statistical explanation that these variables do accomplish is rather uninformative from a causal standpoint. Cognitive performance presumably measures a skill that is rewarded for its contribution to production. But what do schooling and parental status-not to mention keeping a clean house-contribute, independently of cognitive skill? To answer to this question we have stressed the incompleteness of the labor contract and the importance of labor market disequilibria. In addition to the productive skills emphasized by the Walrasian paradigm, we have introduced the Schumpeterian traits (both cognitive and non-cognitive) contributing to individuals' capacity to capture disequilibrium quasi-rents, and the Coasean traits we defined as 'incentive-enhancing preferences,' including such personality traits as a sense of efficacy, as well as avoiding aggressive and disruptive behaviors, as determinants of earnings.

Our resulting behavioral model provides the following resolution to the puzzles with which we began. First, the unexplained variance in the standard earnings function is due in part to individual differences in behavioral traits that are rewarded on labor markets, and not captured by the usual measures of schooling, work experience and cognitive performance. Second, the contribution of schooling and parental socioeconomic status to earnings is in part explained by earnings-enhancing behaviors learned or genetically transmitted from parents and enhanced or signaled by additional years of schooling. Third, the apparent labor market returns to such traits as good housekeeping and slim figures reflect the covariation of these traits with behaviors sought by employers-in the case of these two examples, perhaps, conformity with appropriate behavior, and self-control. Finally, the apparently contradictory evidence on the effectiveness of school resources may not be a puzzle at all. If incentive enhancing preferences and other behavioral traits are important determinants of earnings, and if some of these are fostered by more or higher quality schooling, enhanced school resources may have important effects on subsequent earnings without having similarly large effects on cognitive achievement.

While the evidence for this model is far from definitive, we are prepared to offer the following implications. First, policies to raise individual earnings, and research seeking to explain low earnings and the recent increase in earnings inequality, would benefit from a more inclusive view of the individual traits affecting earnings, one going beyond cognitive traits and productive skills (Murnane and Levy 1996) to include behaviors. 
Second, and partly for this reason, attempts to understand the intergenerational persistence of economic status and income by means of the inheritance of wealth or cognitive capacities, or the granting of educational advantages, will remain inadequate, and would be enhanced by taking account of Schumpeterian and Coasean behavioral traits.

Third, incentive enhancing preferences are probably irreducibly heterogeneous. We are not likely to find a noncognitive behavioral or personality analogue to the common factor $g$ underlying most measures of cognitive performance. If the importance of incentive-enhancing preferences arises from the behavioral demands of the job, traits that count in some jobs might not count in others. Self-direction may contribute to the earnings of someone fairly high up in the chain of command, for instance while penalizing someone at the bottom. Similarly, as we have seen, traits may count differently for men and women, or for different ethnic or language groups.

Fourth, the fact that labor market success may contribute to the development of incentive-enhancing preferences, as well as what we have termed 'Schumpeterian' traits contributing to capturing disequilibrium rents, reinforces the likelihood that poverty may persist over generations within families. Fong (2000) found, for example, that negative income shocks increased individuals' sense of fatalism, suggesting that a low sense of efficacy may contribute to low earnings which then reinforces a low sense of efficacy. "Self-direction," which we identified above as a trait contributing to success in disequilibrium labor market, has been shown by Kohn and his coauthors to be enhanced by occupying positions relatively high up in the authority structure of firms. The estimates by Goldsmith et al. (1997) of the effect of personality on earnings suggests an analogous "self esteem" poverty trap. Labor market research along these lines might both illuminate and benefit from the well established literature on cultural poverty traps in sociology.

Finally, while improving earnings-enhancing cognitive skills is probably welfare increasing for students and is thus an uncontroversial objective of schooling, the same cannot be said of all incentive enhancing preferences. Many will balk at the idea that schools should inculcate the beliefs that it is shameful to be without a job, or to receive unemployment insurance benefits - both of which, as we have seen, count as incentive-enhancing preferences. The same caution applies to fostering traits such as aggression in high status males or the psychological dimension termed "Machiavellianism" (measured by the extent of agreement with statements from Nicolo Machiavelli's The Prince), which has been shown to increase earnings but which many would consider a character flaw. 


\section{REFERENCES}

Alderman, Harold, Jere R. Behrman, David Ross, and Richard Sabot, "The Returns to Endogenous Human Capital in Pakistan's Rural Wage Labor Market," Oxford Bulletin of Economics and Statistics 58,1 (February 1996):29-55.

Altonji, Joseph G., "The Effects of High School Curriculum on Education and Labor Market Outcomes," Journal of Human Resources (Summer 1995):410-438.

Altonji, Joseph G. and Thomas Dunn, "The Effects of Family Characteristics on the Returns to Schooling," Review of Economics and Statistics 78,4 (November 1996):692-704.

Andrisanni, Paul J., "Internal-External Attitudes, Personal Initiative and the Labor Market Experience of Black and White Men," Journal of Human Resources 12 (Summer 1977):308-338.

- , "Internal-External Attitudes, Personal Initiative and Labor Market Experience," in Paul J. Andrisanni (ed.) Work Attitudes and Labor Market Experience (New York: Praeger Publishers, 1978) pp. ??-??

— , Work Attitudes and Labor Market Experience (New York: Praeger, 1978).

- and Gilbert Nestel, "Internal-External Control as Contributor to and Outcome of Work Experience," Journal of Applied Psychology 61,2 (1976):156-165.

Ashenfelter, Orley and Alan Krueger, "Estimates of the Economic Return to Schooling from a New Sample of Twins," American Economic Review 84,5 (December 1994):1157-1172.

Ashenfelter, Orly, Colm Harmon, and Hellse Oosterbeek, "A Review of Estimates of the Schooling/Earnings Relationship, with Tests for Publication Bias," 1999. Princeton University Industrial Relations Section Working Paper 425.

Atkinson, A. B., A. K. Maynard, and C. G. Trinder, Parents and Children: Incomes in Two Generations (London: Heinemann, 1983).

Averett, Susan and Sanders Korenman, "The Economic Reality of The Beauty Myth," Journal of Human Resources 31,2 (Spring 1996):304-330.

Bajema, C. J., "A Note on the Interrelations Among Intellectual Ability, Education Attainment, and Occupational Achievement: A Follow-Up Study of a Male Kalamazoo Public School Population," Sociology of Education 41,3 (Summer 1968):317-319.

Barrick, Murray R. and Michael Mount, "The Big Five Personality Dimensions and Job Performance: A Meta-Analysis," Personnel Psychology 44 (1991):1-26.

Becker, Gary, Human Capital (New York: Columbia University Press, 1964).

Becker, Gary S. and Casey B. Mulligan, "The Endogenous Determination of Time Preference," Quarterly Journal of Economics 112,3 (August 1997):729-759. 
Behrman, Jere, Human Resource Led Development? Review of issues and Evidence (New Delhi: International Labour Organization, 1990). World Employment Programme, Asian Regional Team for Employment Promotion; distributed by ILO, Geneva.

—, Mark Rosenzweig, and Paul Taubman, "Endowments and the Allocation of Schooling in the Family and in the Marriage Market: The Twins Experiment," Journal of Political Economy 102,6 (1994):1131-1174.

Betts, Julian R., "Does School Quality Matter? Evidence From the National Longitudianl Survey of Youth," Review of Economics and Statistics 77,2 (1995):231247.

Bishop, John, "Is the Test Score Decline Responsible for the Productivity Growth Decline?," American Economic Review 79,1 (1989):178-197.

Bishop, John, "Achievement, Test Scores and Relative Wages," in Marvin Kosters (ed.) Workers and their Wages (Washington, DC: AEI Press, 1991) pp. 146-186.

Blackburn, McKinley L. and David Neumark, "Omitted-Ability Bias and the Increase in the Returns to Schooling," Journal of Labor Economics 11,3 (1993):521-544.

Blau, Peter, Exchange and Power in Social Life (New York: John Wiley, 1964).

Boissière, M., J. B. Knight, and R. H. Sabot, "Earnings, Schooling, Ability, and Cognitive Skills," American Economic Review 75,5 (December 1985):10161030.

Bowles, Samuel, "Migration as Investment: Empirical Tests of the Human Investment Approach to Geographical Mobility," Review of Economics and Statistics 52,4 (1970):356-362.

— , "Schooling and Inequality from Generation to Generation," Journal of Political Economy 80,3 (May/June 1972):S219-251.

- , "The Production Process in a Competitive Economy: Walrasian, Neo- Hobbesian, and Marxian Models," American Economic Review 75,1 (March 1985):1636.

- and Herbert Gintis, Schooling in Capitalist America: Educational Reform and the Contradictions of Economic Life (New York: Basic Books, 1976).

- and - , "Incentive Enhancing Preferences," 1999. University Massachusetts.

— and - , "The Inheritance of Economic Status," Journal of Economic Perspectives (2001).

- and Valerie Nelson, “The 'Inheritance of IQ' and the Intergenerational Reproduction of Economic Inequality,' Review of Economics and Statistics 56,1 (February 1974). 
— , Herbert Gintis, and Melissa Osborne, "Incentive-Enhancing Preferences: Personality, Behavior and Earnings," American Economic Review 92,2 (May 2001):??-??.

Bureau of the Census, "First Findings from the EQW National Employer Survey," 1998. EQW Catalog Number RE01.

Burtless, Gary, Does Money Matter? The Effect of School Resources on Student Achievement and Adult Success (Washington, DC: The Brookings Institution Press, 1996).

Cameron, Steven and James Heckman, "The Non-equivalence of the High School Equivalents," Journal of Labor Economics 11,1 (1993):1-47.

Card, David, "Using Geographic Variation in College Proximity to Estimate the Return to Schooling," October 1993. NBER Working Paper No. 4483.

Card, David, "Earnings, School, and Ability Revisited," Research in Labor Economics 14 (1995):23-48.

- , "The Causal Effect of Education on Earnings," in Orley Ashenfelter and David Card (eds.) Handbook of Labor Economics, Vol. 3 (Amsterdam: North-Holland, 1998).

- and Alan B. Krueger, "Labor Market Effects of School Quality: Theory and Evidence," in Gary Burtless (ed.) Does Money Matter? The Effect of School Resources on Student Achievement and Adult Success (Washington, D. C.: Brookings Institution Press, 1996) pp. 97-140.

Cawley, John, James Heckman, Lance Lochner, and Edward Vytlacil, "Understanding the role of cognitive ability in accounting for the recent rise in the return to education," in Kenneth Arrow, Samuel Bowles, and Steven Durlauf (eds.) Meritocracy and Economic Inequality (Princeton, NJ: Princeton University Press, 2000) pp. 230-266.

Cawley, John, Karen Conneely, James Heckman, and Edward Vytlacil, "Measuring the Effects of Cognitive Abilities," in Bernie Devlin, Stephen E. Fienberg, Daniel P. Resnick, and Kathryn Roeder (eds.) Intelligence, Genes, and Success: Scientists Respond to the Bell Curve (New York: Springer, Copernicus, 1997).

Chamberlain, Gary and Zvi Griliches, "Unobservables with a VarianceComponents Structure: Ability, Schooling, and the Economic Success of Brothers," International Economic Review 16,2 (June 1975):422-449.

Christie, R. and F. Geis, Studies in Machiavellianism (New York: Academic Press, 1970).

Coase, Ronald H., "The Nature of the Firm," Economica 4 (November 1937):386405.

Conlisk, John, "A Bit of Evidence on the Income-Education-Ability Interaction," Journal of Human Resources 6,3 (Summer 1971):358-362. 
Cutright, Phillips, "Achievement, Mobility and the Draft: Their Impact on the Earnings of Men," Technical Report, U. S. Department of Health, Education, and Welfare, Social Security Administration, Office of Research and Statistics (June 1972). Staff Paper No. 14.

Cutright, Phillips, "Region, Migration and Earnings of White and Black Men," Social Forces 53,2 (December 1974):297-305.

Dearden, Lorraine, Stephen Machin, and Howard Reed, "Intergenerational Mobility in Britain," Economic Journal 107,440 (1997):47-66.

Devlin, Bernie, Michael Daniels, and Kathryn Roeder, "The Heritability of IQ," Nature 388 (31 July 1997):468-471.

Donohue, J. and P. Siegelman, "Allocating Resources among Prisons and Social Programs in the Battle Against Crime," Journal of Legal Studies 27,1 (1998):143.

Dreeben, Robert, On what is Learned in School (Reading, MA: Addison-Wesley, 1967).

Duncan, Greg and James Morgan, "Sense of Efficacy and Subsequent Change in Earnings: A Replication," Journal of Human Resources 16,4 (1981):649-657.

Duncan, Greg J. and Rachel Dunifon, "'Soft-Skills' and Long-Run Market Success," Research in Labor Economics (October 1997):1-42.

- and - , "Long-Run Effects of Motivation on Labor-Market Success," Social Psychology Quarterly 61,1 (1998):33-48.

Duncan, Otis Dudley, “Ability and Achievement," Eugentics Quarterly 15,1 (March 1968).

- , David L. Featherman, and Beverly Duncan, "Socioeconomic Background and Occupational Achievement," Technical Report, U. S. Department of Health, Education and Welfare (May 1968). Project No. S-0074 (EO-191).

Durso, Francis T., "Situation Awareness as a Predictor of Performance in En Route Air Traffic Controllers," 1999. U.S. Department of Transportation, Federal Aviation Administration.

Edwards, Richard C., "Personal Traits and 'Success' in Schooling and Work," Educational and Psychological Measurement 37 (1976):125-138.

Eysenck, H. J., "Intelligence and Introversion-extraversion," in Robert J. Sternberg and Patricia Ruzgis (eds.) Personality and Intellegence (Cambridge University Press, 1994) pp. 3-31.

Fallick, Bruce Chelimsky, "The Industrial Mobility of Displaced Workers," Journal of Labor Economics 11,2 (1993):302-323.

Farber, Henry S., "The Changing Face of Job Loss in the United States, 1981-1993," Industrial Relaions Section (March 1996):1-71. 
Farkas, George, Paula England, Keven Vicknair, and Barbara Stanek Kilbourne, "Cognitive Skill, Skill Demands of Jobs, and Earnings Among Young European American, African American, and Mexican American Workers," Social Forces 75,3 (March 1997):913-940.

Filer, Randall Keith, "The Influence of Affective Human Capital on the Wage Equation," Research in Labor Economics 4 (1981):367-416.

Fisher, Janet A., Kenneth G. Lutterman, and Dorothy M. Ellegard, "Post-High School Earnings: When and For Whom Does 'Ability' Seem to Matter?," April 1973. University of Wisconsin: Social Systems Research Institute.

Flynn, James R., "IQ Trends Over Time: Intelligence, Race and Meritocracy," in Kenneth Arrow, Samuel Bowles, and Steven Durlauf (eds.) Meritocracy and Economic Inequality (Princeton University Press, 2000) pp. 35-60.

Fong, Christina, "Social Insurance or Conditional Generosity: The Role of Beliefs about Self- and Exogenous-Determination of Incomes in Redistributive Politics," 2000. Washington University Department of Political Science.

Foster, Andrew D. and Mark R. Rosenzweig, "Information, Learning, and Wage Rates in Low Income Rural Areas," Journal of Human Resources XXVIII,4 (Fall 1993):759-790.

Gable, Myron and Frank Dangello, "Locus of Control, Machiavellianism, and Managerial Job Performance,” Journal of Psychology 128,5 (1994):599-608.

Ghiselli, Edwin E. and Richard P. Barthol, "The Validity of Personality Inventories in the Selection of Employees," The Journal of Applied Psychology 37, 1 (1953):1820.

Gintis, Herbert, "Education, Technology, and the Characteristics of Worker Productivity," American Economic Review 61,2 (1971):266-279.

- , "The Nature of the Labor Exchange and the Theory of Capitalist Production," Review of Radical Political Economics 8,2 (Summer 1976):36-54.

- and Tsuneo Ishikawa, "Wages, Work Discipline, and Unemployment," Journal of Japanese and International Economies 1 (1987):195-228.

Glaeser, Edward L. and DiPasquale, "Incentives and Social Capital: Are Homeowners Better Citizens?," Journal of Urban Economics 45,2 (1999):354-384.

Glewwe, Paul, "The Relevance of Standard Estimates of Rates of Return to Schooling for Education Policy: A Critical Assessment," Journal of Development Economics 51,2 (December 1996):267-290.

Goldsmith, Arthur, Jonathan Veum, and William Darity, "The Impact of Psychological and Human Capital on Wages," Economic Inquiry 35 (October 1997):815829. 
Green, Francis, Stephen Machin, and David Wilkenson, "The Meaning and Determinants of Skill Shortages," Oxford Bulletin of Economics and Statistics 60,2 (May 1998):165-188.

Green, Leonard, Joel Myerson, David Lichtman, Suzanne Rosen, and Astrid Fry, "Temporal Discounting in Choice Between Delayed Rewards: The Role of Age and Income," Psychology and Aging 11,1 (1996):79-84.

Griliches, Zvi and B. Mason, "Education, Income and Ability," Journal of Political Economy 80,3 (May/June 1972).

Grogger, Jeff and Eric Eide, "Changes in College Skills and the Rise in the College Wage Premium," Journal of Human Resources 30,2 (1995):280-310.

Guion, Robert, "Comments on Hunter," in Frank Landy, Sheldon Zedeck, Jeanette Cleveland, and Ann Landy (eds.) Performance Measurement and Theory (Hillsdale: Lawrence Erlbaum Associates Publishers, 1983) pp. 267-275.

Gustafson, Cynthia, "Job Displacement and Mobility of Younger Workers," November 1998. Center for Labor Economics, University of California at Berkeley.

Hamermesh, Daniel and Jeff Biddle, "Beauty and the Labor Market," American Economic Review 84,5 (December 1994):1174-1194.

Hansen, W. Lee, Burton A. Weisbrod, and William Scanlon, "Schooling and Earnings of Low Achievers," American Economic Review (June 1970):409-418.

Hause, John C., "Earnings Profile: Ability and Schooling," Journal of Political Economy 80,3 (May/June 1972):S108-S138.

Hauser, Robert and Min-Hsiung Huang, "Verbal Ability and Socioeconomic Success: A Trend Analysis," Social Science Research 26 (1997):331-376.

Hauser, Robert, Kenneth Lutterman, and William Sewell, "Socioeconomic Background, Ability and Achievement," in William Sewell and Robert Hauser (eds.) Education, Occupation, and Earnings (New York: Academic Press, 1975).

Hausman, Jerry, "Individual Discount Rates and the Purchase and Utilization of Energy-using Durables," Bell Journal of Economics 10,1 (Spring 1979):33-54.

Heckman, James, "Policies to Foster Human Capital," Research in Economics 54 (2000):3-56.

- , The GED ( forthcoming).

— , Anne Layne-Farrar, and Petra Todd, "Does Measured School Quality Really Matter? An Examination of the Earnings-Quality Relationship," in Gary Burtless (ed.) Does Money Matter? The Effect of School Resources on Student Achievement and Adult Success (Washington, D.C.: Brookings Institution Press, 1996) pp. 192-289.

Heckman, Jingjing Hsee, and Yona Rubinstein, "The GED as a Mixed Signal," 1999. University of Chicago. 
Huang, Min-Hsiung, "Historical Changes in the Effects of Verbal Ability on Socioeconomic Success in the United States," March 1996. University of Wisconson, Madison.

Hunter, John E., "Cognitive Ability, Cognitive Aptitudes, Job Knowledge, and Job Performance," Journal of Vocational Behavior 29 (1986):340-362.

Jencks, Christopher, Who Gets Ahead? (New York: Basic Books, 1979).

Jencks, Christopher and Meredith Phillips, The Black White Test Score Gap (Washington, DC: The Brookings Institution Press, 1998).

- and - , "Aptitude or Achievement: Why do Test Scores Predict Educational Attainment and Earnings?," in Susan Mayer and Paul Peterson (eds.) Cognitive and Social Skills: Sources, Consequences, and Policy (Washington, DC: The Brookings Institution, forthcoming).

Jensen, Arthur, "Patterns of Mental Ability and Socioeconomic Status," Proceedings of the National Academy of Sciences 60,4 (August 1968):1330-1337.

Juhn, Chinhui, Kevin Murphy, and Brooks Pierce, "Wage Inequality and the Rise in Returns to Skill," Journal of Political Economy 101,1 (1993):410-442.

Kane, Thomas and Cecilia Elena Rouse, "Labor Market Returns to Two- and FourYear College: Is a Credit a Credit and Do Degrees Matter?," American Economic Review 85,3 (June 1995).

Katz, Lawrence and Kevin Murphy, "Changes in Relative Wages, 1963-1987: Supply and Demand Factors," Quarterly Journal of Economics (1992):35-78.

Kerckhoff, Alan, Richard Campbell, and Jerry Trott, "Class, Stratification, and psychological Functioning," American Sociological Review 47 (1982):347-364.

Lally, J., P. Mangione, and A. Honig, "The Syracuse University Family Development Research Program: Long-Range Impact on an Early Intervention with Low-Income Children and Their Families," in D. Powell (ed.) Parent Education as Early Childhood Intervention (Norwood: Ablex, 1988) pp. 79-104.

Lavy, Victor, Jennifer Spratt, and Nathalie Leboucher, "Patterns of Incidence and Change in Moroccan Literacy," Comparative Education Review41,2 (May 1997).

Loh, Eng Seng, "The Economic Effects of Physical Appearance," Social Science Quarterly 74,2 (June 1993):420-438.

Long, D., C. Mallar, and C. Thorton, "Evaluating the Benefits and Costs of the Job Corps," Journal of Policy Analysis 1,81 (1981):55-76.

Magnani, Elisbetta, "Human Capital, Industry Risk and Industrial Labor Mobility," 1997. University of New South Wales.

Maxwell, Nan, "The Effect on Black-White Wage Differences of Differences in the Quantity and Quality of Education," Industrial and Labor Relations Review 47,2 (January 1994):249-264. 
Miner, J. B., Intelligence in the U.S: A Survey (New York: Springer, 1957).

Moll, Peter, "Primary Schooling, Cognitive Skills and Wages in South Africa," June 1995. Unpublished.

Mulligan, Casey, "Personal correspondence," December 26 1997. Unpublished regression results.

Mulligan, Casey, "Galton vs. the Human Capital Approach to Inheritance," Journal of Political Economy (1999).

Murnane, Richard and Frank Levy, Teaching the New Basic Skills (New York: The Free Press, 1996).

Murnane, Richard, John B. Willett, and Frank Levy, "The Growing Importance of Cognitive Skills in Wage Determination," Review of Economics and Statistics 77,2 (May 1995):251-266.

Murnane, Richard, John Willett, and John Tyler, "Who Benefits from Obtaining a GED? Evidence from High School $n$ and Beyond," 1998. Harvard Graduate School of Education.

— , _ , Jay Braatz, and Yves Duhaldeborde, "Does the Self-Esteem of High School Aged Males Predict Labor Market Success a Decade Later? Evidence from the NLSY," 1997. Harvard University Graduate School of Education.

Nelson, Richard R. and Edmund S. Phelps, "Investment in Humans, Technological Diffusion, and Economic Growth," American Economic Review 56,2 (May 1966):69-75.

Okanes, Marvin M. and Murray William, "Achievement and Machiavellianism Among Men and Women Managers," Psychological Reports 46 (1980):783-788.

O'Neil, June, “The Role of Human Capital in Earnings Differences Between Black and White Men," Journal of Economic Perspectives 4,4 (fall 1990):25-45.

Osborne, Melissa, "The Power of Personality: Labor Market Rewards and the Transmission of Earnings," 2000. University of Massachusetts.

Otto, Sarah P., Freddy B. Christiansen, and Marcus W. Feldman, "Genetic and Cultural Inheritance of Continuous Traits," 1995. Working Paper No. 0064. Morrison Institute for Population and Resource Studies, Stanford University.

Parsons, Talcott, "The School Class as a Social System," Harvard Educational Review 29 (1959):297-318.

Porter, James N., "Race, Socialization, and Mobility in Education and Early Occupational Attainment," American Sociological Review 39 (June 1974):303-316.

Ree, Malcolm James, James E. Earles, and Mark S. Teachout, "Predicting Job Performance: Not Much More Than g," Journal of Applied Psychology 79,4 (1994):518-524. 
Register, Charles and Donald Williams, "Wage Effects of Obesity among Young Workers," Social Science Quarterly 71,1 (March 1990):130-141.

Rogers, William and William Spriggs, "What Does the AFQT Really Measure: Race, Wages, Schooling and the AFQT Score," Review of Black Political Economy (Spring 1996):13-46.

Rosenzweig, Mark R., "Why Are There Returns to Schooling, Household Savings and Human Investment in Development," American Economics Association Papers and Proceedings 85,2 (May 1995):153-158.

Rotter, J. B., "Generalized Expectancies for Internal vs. External Control of Reinforcement," Psychological Monographs 80,609 (1966).

Rubinstein, Yona and Daniel Tsiddon, "Born to be Unemployed: Unemployment and Wages Over the Business Cycle," 1999. University of Chicago and Tel Aviv University and the CEPR.

Sargent, James and David Blanchflower, "Adolescent Obesity and Socioeconomic Status Seven Years Later: Do Fat Children Earn Less as Adults?,” February 1998. unpublished.

Schmidt, Frank L. and John E. Hunter, "The Validity and Utility of Selection Methods in Personnel Psychology: Practical and Theoretical Implications of 85 Years of Research Findings," Psychological Bulletin 124,2 (1998):262-274.

Schultz, Clifford J., "Situational and Dispositional Predictors of Performance: A Test of the Hypothesized Machiavellianism X Structure Interaction Among Sales Persons," Journal of Applied Social Psychology 23 (1993):478-498.

Schultz, T. W., "The Value of the Ability to Deal with Disequilibria," Journal of Economic Literature 13 (1975):872-876.

Schumpeter, Josesph A., The Theory of Economic Development (London: Oxford University Press, 1934).

Schwartz, Aba, "On Efficiency of Migration," Journal of Human Resources 6,2 (Spring 1971):194-205.

Schweinhart, L., H. Barnes, and D. Weikart, Significant Benefits: The High/Score Perry Pre-School Study Through Age 27(Ypsilanti, MI: High Scope Press, 1993).

Seitz, V., Intervention Programs for Impoverished Children: A Comparison of Educational and Family Support Models (London: Jessica Kingsley Publishers, 1990). Annals of Child Development, Vol. 7.

Sewell, William H., Archibald P. Haller, and George W. Ohlendorf, "The Education and Early Occupational Status Achievement Process," American Sociological Review 35,6 (December 1970):1014-1027.

Shapiro, Carl and Joseph Stiglitz, "Unemployment as a Worker Discipline Device," American Economic Review 74,3 (June 1984):433-444. 
Sobal, J., "Obesity and Socioeconomic Status: A Framework for Examining Relationships Between Physical and Social Variables," Medical Anthropology 13 (1991):231-247.

- and A. J. Strunkard, "Socioeconomic Status and Obesity: A Review of the Literature," Psychological Bulletin 105 (1989):260-275.

Solon, Gary R., "Intergenerational Income Mobility in the United States," American Economic Review 82,3 (June 1992):393-408.

Sternberg, Robert J., Richard K. Wagner, Wendy M. Williams, and Joseph Horvath, “Testing Common Sense," American Psychologist 50,11 (November 1995):912927.

Strunkard, A. J. and T. I. Sorensen, "Obesity and Socioeconomic Status-A Complex Relation," New England Journal of Medicine 329 (1993).

Taber, Christopher R., "The Rising College Premium in the Eighties: Return to College or Return to Ability?," June 1997. Department of Economics and Institute for Policy Research, Northwestern University.

Taggart, R., Quantum Opportunity Program Opportunities (Philadelphia: Industrialization Center of America, 1995).

Taubman, Paul and Terence Wales, Higher Education and Earnings; College as an Investment and a Screening Device (New York: McGraw-Hill, 1974).

Tett, Robert P., Douglas N. Jackson, and Mitchell Rothstein, "Personality Measures as Predictors of Job Performance: A Meta-Analytic Review," Personnel Psychology 44 (1991):703-742.

Thorndike, Edward L., "Intelligence and Its Uses," Harper's Monthly Magazine 140 (December/January 1919):227-235.

Tierney, J. and J. Grossman, Making a Difference: An Impact Study of Big Brothers/Big Sisters (Philadelphia: Public/Private Ventures, 1995).

Turner, Charles F. and Daniel C. Martinez, "Socioeconomic Achievement and the Machiavellian Personality," Sociometry 40,4 (1977):325-336.

Walras, Leon, Elements of Pure Economics (London: George Allen and Unwin, 1954 [1874]).

Welch, Finis, "Education in Production," Journal of Political Economy 8,1 (Jan/Feb 1970):35-59.

Williams, Wendy M. and Robert J. Sternberg, Success Acts for Managers (Florida: Harcourt Brace, 1995).

Winship, Christopher and Sanders Korenman, "Do Schools Raise IQ?," in Bernie Devlin, Stephen E. Fienberg, Daniel P. Resnick, and Kathryn Roeder (eds.) Intelligence, Genes, and Success: Scientists Respond to the Bell Curve (New York: Springer, Copernicus, 1997). 
Zimmerman, David J., "Regression Toward Mediocrity in Economic Stature," American Economic Review 82,3 (June 1992):409-429.

e: $\backslash$ papers $\backslash$ JEL paper $\backslash$ Determinants of Earnings.tex January 26, 2001 